\title{
The effects of biomanipulation on the biogeochemistry, carbon isotopic composition and pelagic food web relations of a shallow lake
}

\author{
B. M. Bontes ${ }^{1}$, R. Pel ${ }^{1}$, B. W. Ibelings ${ }^{1}$, H. T. S. Boschker ${ }^{2}$, J. J. Middelburg ${ }^{2}$, and E. Van Donk ${ }^{1}$ \\ ${ }^{1}$ Centre for Limnology, Netherlands Institute of Ecology (NIOO-KNAW), Rijksstraatweg 6, 3631 AC Nieuwersluis, The \\ Netherlands \\ ${ }^{2}$ Centre for Estuarine and Marine Ecology, Netherlands Institute of Ecology (NIOO-KNAW), Korringaweg 7, 4401 NT \\ Yerseke, The Netherlands
}

Received: 21 June 2005 - Published in Biogeosciences Discuss.: 10 August 2005

Revised: 20 December 2005 - Accepted: 9 January 2006 - Published: 2 March 2006

\begin{abstract}
In this study we investigated the effects of experimental biomanipulation on community structure, ecosystem metabolism, carbon biogeochemistry and stable isotope composition of a shallow eutrophic lake in the Netherlands. Three different biomanipulation treatments were applied. In two parts of the lake, isolated from the rest, fish was removed and one part was used as a reference treatment in which no biomanipulation was applied. Stable isotopes have proved useful to trace trophic interactions at higher food web levels but until now methodological limitations have restricted species specific isotope analysis in the plankton community. We applied a new approach based on the combination of fluorescence activated cell sorting (FACS) and isotope ratio mass spectrometry (IRMS) to trace carbon flow through the planktonic food web. With this method we aimed at obtaining group specific $\delta^{13} \mathrm{C}$ signatures of phytoplankton and to trace possible shifts in $\delta^{13} \mathrm{C}$ resulting from fish removal.
\end{abstract}

Biomanipulation led to an increase in transparency and macrophyte biomass and decrease in phytoplankton abundance, but zooplankton numbers did not increase. Fish removal also resulted in high $\mathrm{pH}$, high $\mathrm{O}_{2}$, low $\mathrm{CO}_{2}$ and more negative $\delta^{13} \mathrm{C}_{\mathrm{DIC}}$ values than expected, which is attributed to chemical enhanced diffusion with large negative fractionation. Despite high temporal variation we detected differences between the isotopic signatures of the primary producers and between the different treatments. The fractionation values of green algae $(\sim 21 \%$ o $)$ and diatoms $(\sim 23 \%$ o $)$ were similar and independent of treatment, while fractionation factors of filamentous cyanobacteria were variable between the treatments that differed in $\mathrm{CO}_{2}$ availability. ${ }^{13} \mathrm{C}$-labeling of the phytoplankton groups showed that biomanipulation led to increased growth rates of green algae and diatoms at the expense of cyanobacteria. Finally, consumers seemed generalists to the available food sources.

Correspondence to: B. M. Bontes

(b.bontes@nioo.knaw.nl, bbontes@yahoo.com)

\section{Introduction}

Over the last decades, biomanipulation of lakes has become a popular tool to assist lake restoration. However, the results of biomanipulation may be variable and biomanipulation does not always lead to the desired improvement of water quality (Jeppesen et al., 1997). The failure of biomanipulation is often attributed to the complexity of lacustrine food web structure. In earlier studies, quantitative effects of fish removal on higher trophic levels have been described in detail (Meijer et al., 1999), but effects of fish reduction on $\mathrm{CO}_{2}, \mathrm{O}_{2}, \mathrm{pH}$ dynamics and carbon fluxes in the seston of especially shallow lakes are largely unknown. Schindler et al. (1997) were the first to observe that manipulation of predators and the consequent shift in grazers had a dramatic impact on lake $\mathrm{CO}_{2}$ concentrations and the exchange of $\mathrm{CO}_{2}$ across the air-water interface. They also observed that shifts in isotopic composition of algae (seston), zooplankton and fish were linked. Subsequently, Cole et al. (2000) and Carpenter et al. (2001) confirmed the observations regarding the dynamic response of $\mathrm{O}_{2}$ and $\mathrm{CO}_{2}$ concentrations to biomanipulation. Recently, Bade et al. (2004) reported that biomanipulation induced not only low $\mathrm{CO}_{2}$ concentrations but also may result in depleted $\delta^{13} \mathrm{C}$ values of dissolved inorganic carbon due to chemical enhanced diffusion at high $\mathrm{pH}$ values.

During the last decades, stable isotopes have proved useful to trace trophic interactions at higher food web levels (Peterson and Fry, 1987; Kling et al., 1992; Keough et al., 1996), but methodological limitations have restricted species specific isotope analysis in the plankton community. New approaches based on the combination of biomarkers and stable isotope ratio mass spectrometry (IRMS; Boschker and Middelburg, 2002) or the combination of flow cytometry and IRMS (Pel et al., 2003, 2004a) have recently been used to trace carbon flow through the microbial domain. Pel et al. (2003) demonstrated, in this way, for the shallow Lake Loosdrecht, that natural differences in isotopic signatures of

Published by Copernicus GmbH on behalf of the European Geosciences Union. 
Table 1. Characteristics of the three treatments; water chemistry figures are annual means based on regular measurements from FebruaryDecember 2003. Ranges are the minimal and maximal values observed during this period.

\begin{tabular}{|c|c|c|c|c|c|c|c|c|c|}
\hline & $\begin{array}{l}-\mathrm{FW} \\
\text { Mean }\end{array}$ & Range & $\mathrm{N}$ & $\begin{array}{l}-\mathrm{W} \\
\text { Mean }\end{array}$ & Range & $\mathrm{N}$ & $\begin{array}{l}\mathrm{R} \\
\text { Mean }\end{array}$ & Range & $\mathrm{N}$ \\
\hline Secchi depth $\left(\mathrm{cm}^{-1}\right)$ & 85 & $65-100$ & 19 & 65 & $35-90$ & 19 & 65 & 30-90 & 19 \\
\hline $\mathrm{pCO}_{2}(\mathrm{ppmv})$ & 2267 & $0.7-10152$ & 19 & 1974 & $255-8379$ & 19 & 951 & $72-2266$ & 19 \\
\hline $\mathrm{CO}_{2}\left(\mu \mathrm{mol} \mathrm{L}{ }^{-1}\right)$ & 100.9 & $0.03-371$ & 19 & 91.4 & $10.5-485$ & 19 & 45.7 & $2.4-185.5$ & 19 \\
\hline $\mathrm{HCO}_{3}^{-}\left(\mu \mathrm{mol} \mathrm{L}^{-1}\right)$ & 735.6 & $193.5-2814.8$ & 13 & 1028.4 & $428.3-2897.7$ & 13 & 937.3 & $445.0-2685.1$ & 11 \\
\hline $\mathrm{CO}_{3}^{2-}\left(\mu \mathrm{mol} \mathrm{L}^{-1}\right)$ & 92.6 & $4.6-85.6$ & 13 & 14.7 & $1.2-73.5$ & 13 & 27.7 & $4.6-85.6$ & 11 \\
\hline $\mathrm{O}_{2}(\%$ saturation $)$ & 89.0 & $40.8-158$ & 17 & 83.8 & $48.5-133.8$ & 17 & 95.4 & $58.5-146.1$ & 17 \\
\hline $\mathrm{TP}\left(\mathrm{mg} \mathrm{P}+\mathrm{PO}_{4}^{-} / \mathrm{L}^{-1}\right)$ & 0.10 & $0.05-0.2$ & 16 & 0.15 & $0.06-0.3$ & 17 & 0.14 & $0.07-0.2$ & 17 \\
\hline $\mathrm{TN}\left(\mathrm{mg} \mathrm{N} \mathrm{L}^{-1}\right)$ & 1.70 & $0.8-2.5$ & 15 & 1.69 & $0.3-2.7$ & 15 & 2.03 & $1.1-3.8$ & 15 \\
\hline Chl. $a\left(\mu \mathrm{g} \mathrm{L}^{-1}\right)$ & 26.0 & $1.7-48.2$ & 18 & 40.0 & $6.5-87.4$ & 18 & 57.8 & $5.5-119$ & 18 \\
\hline $\mathrm{pH}$ & 7.6 & $6.3-10.4$ & 19 & 7.4 & $6.3-8.1$ & 19 & 7.8 & $7.3-8.6$ & 19 \\
\hline Temperature $\left({ }^{\circ} \mathrm{C}\right)$ & 15.2 & $2.9-24.5$ & 19 & 15.4 & $2.8-25.2$ & 19 & 15.8 & $3.7-25.9$ & 19 \\
\hline Eukaryotes $\left(10^{3}\right.$ cells $\left.\mathrm{L}^{-1}\right)$ & 26402 & $2092-103850$ & 17 & 54770 & $9033-144834$ & 18 & 48569 & $9909-116213$ & 18 \\
\hline Cyanobacteria $\left(10^{3}\right.$ cells $\left.\mathrm{L}^{-1}\right)$ & 16298 & $1922-88653$ & 17 & 52500 & $9813-174135$ & 18 & 86070 & $12303-287593$ & 18 \\
\hline
\end{tabular}

phytoplankton groups (green algae and cyanobacteria) can be used directly to study carbon transfer from primary to secondary consumers, and to assess preferential grazing by zooplankton. Boschker et al. (2005) used compounds specific isotope analysis of algal and bacterial biomarkers to trace interaction within the microbial domain in the Scheldt estuary.

In this study we will investigate the effects of fish removal on community structure, ecosystem metabolism, carbon biogeochemistry and stable isotope composition of a shallow Dutch lake (Terra Nova). Most Dutch lakes (depth 0.5$1.5 \mathrm{~m}$ ) originate from peat extractions in the 19th century and are characterized by peaty sediment and brown, turbid water rich in humic substances. The majority is highly eutrophic and regular reoccurring blooms of cyanobacteria are an important concern for lake management (Scheffer, 1998).

The main perspective behind the present study is that biomanipulation changes the lower food chain relationships, thereby altering the carbon cycling, which is reflected in the $\mathrm{C}$-isotopic values of dissolved inorganic carbon and primary producers. We will use the unique combination of fluorescence-activated cell sorting and IRMS (Pel et al., 2003, 2004a) to determine end member $\delta^{13} \mathrm{C}$ values for the main phytoplankton groups, a prerequisite for detailed foodweb studies based on stable isotope analysis. Moreover, we expect that changes in the isotopic composition of phytoplankton, due to fish removal, are reflected in the isotope signatures of zooplankton, the main consumers of these algae. Ultimately, the information on carbon isotope ratios $\left(\delta^{13} \mathrm{C}\right)$ of the smaller size classes of the pelagic biota (phytoplankton and zooplankton), before and after fish removal may increase our understanding of ecosystem functioning and improve the predictability of the response of lakes to biomanipulation. The aim of our study was to reveal potential shifts in (a) biogeochemical variables e.g. $\mathrm{O}_{2}$ and $\mathrm{CO}_{2}$; (b) $\delta^{13} \mathrm{C}$ values of DIC, algae and zooplankton, and (c) trophic interactions between seston species, caused by biomanipulation in a eutrophic, shallow lake.

\section{Material and methods}

\subsection{Study site}

In October 2002 a biomanipulation experiment was started in the hypertrophic shallow lake Terra Nova (max. depth $1.5 \mathrm{~m}$ ), which originates from peat extraction in the 19th century (for characteristics see Table 1). The sediment is organic (detritus); the water column completely mixed and highly turbid for a large part of the year. In addition to nutrients already present, Terra Nova receives nutrients by connection (at high water levels) from the nearby hypertrophic lakes Loenderveen and Loosdrecht (Gons et al., 1992). Water quality and biodiversity of Terra Nova have greatly deteriorated during the last 40 years, and the phytoplankton composition has shifted from a mixture of diatoms and green algae to green algae and filamentous cyanobacteria. Presently, the cyanobacteria (Limnothrix, Planktothrix) make up more than $60 \%$ of the total phytoplankton community by number. The zooplankton is characterized by high population densities of detritivorous- and herbivorous species such as bosminids and small rotifers whilst large cladocerans like Daphnia are absent (G. ter Heerdt, personal communication and Appendix A). Submerged macrophytes like Nitella, Chara and Potamogeton are missing, and floating macrophytes (Nuphar and Nymphea spp.) dominate the surface of the lake, in the open water as well as the littoral zone. Bream and roach are present in high densities (bream 89 and roach 


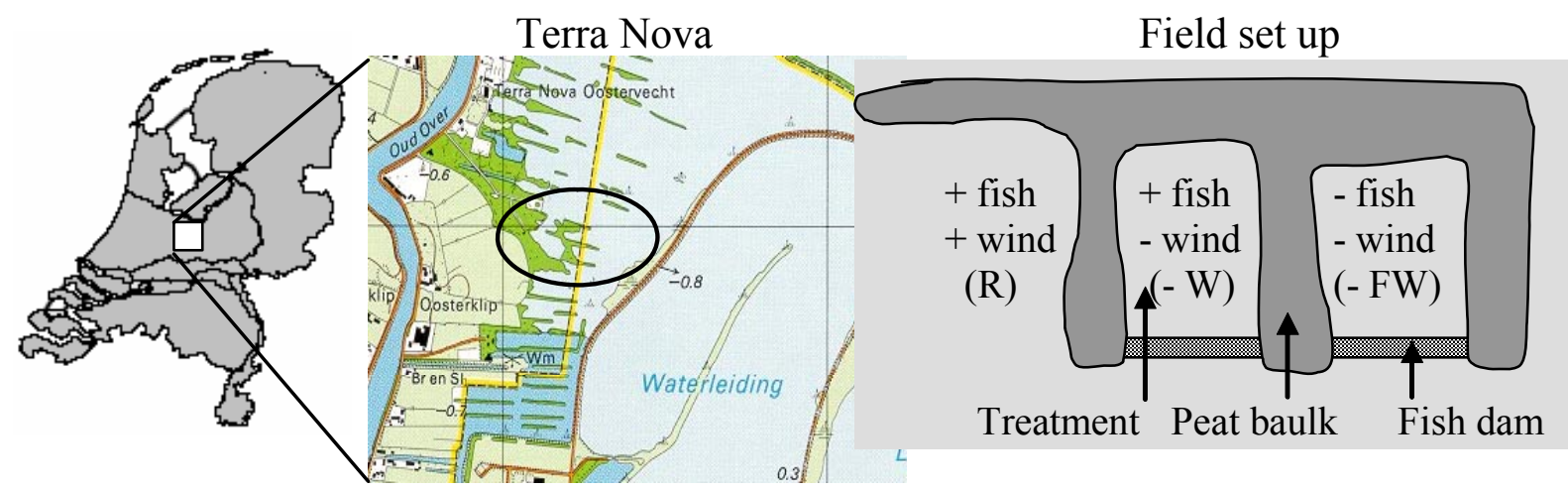

Fig. 1. Location of Terra Nova (Loosdrecht Lakes, the Netherlands) and the design of the biomanipulation experiment in the field.

$9.7 \mathrm{~kg} \mathrm{ha}^{-1}$ ) and are both planktivorous fish species with an early benthic life stage. As a result of these characteristics they may have a profound effect on the turbidity of the water column, either by high grazing rates on zooplankton (main consumers of algae) or resuspension of the sediment. For an insight in the dynamics of the seston and abiotic parameters, before the biomanipulation, monitoring data of the reference area $(\mathrm{R})$ during the three years prior to the start of the experiment are provided in Appendix A.

In September 2002, two shallow lakes (average area $=$ $0.005 \mathrm{~km}^{2}$; average depth $=0.9 \mathrm{~m}$ ) in Terra Nova were isolated from the rest of the lake by wooden dams, to prevent fish migration (Fig. 1). In January 2003, fish was removed from both lakes using nets and electrical fishing. Effectiveness of fish removal was determined by the mark-recapture method of Petersen (1896) with a total reduction of the planktivorous and benthivorous fish stock by almost $75 \%$ (source Witteveen \& Bos). The southern lake was restocked with a known amount and composition of fish, reflecting the average Terra Nova densities (see earlier), whilst the northern lake was left without fish. For correct interpretation it is essential to note that wind, as well as fish, was significantly reduced in both enclosures. The decrease in wind effect may have reduced sediment resuspension and gas exchange across the air-water interface. A reference location adjacent to the two closed lakes and in open contact with the main lake was also monitored; this site was more wind exposed than the biomanipulated enclosures (but less wind exposed than the open water of Terra Nova), and fish conditions were left unchanged. Hereafter we will refer to the different sample locations as - FW ( - fish and - wind), - W (+ fish - wind) and $\mathrm{R}$ (reference; i.e. + fish + wind). Unfortunately a location without fish, but with wind conditions unchanged ( - fish + wind) was not available.

\subsection{Monitoring plankton and abiotic variables}

Water samples were collected (bi) weekly, from FebruaryDecember 2003 from the 3 locations, using a $1.5 \mathrm{~m}$ long tube sampler, which enabled us to sample the entire water column. From a mixed $30 \mathrm{~L}$ sample, a sub sample of $10 \mathrm{~L}$ was brought to the laboratory for analysis. Secchi depth, temperature, $\mathrm{pH}$ and oxygen concentrations were measured in situ (Multiline-P4 meter, WTW, Germany). To monitor phytoplankton abundance, Chl. $a\left(\mu \mathrm{g} \mathrm{L}^{-1}\right)$ of green algae, diatoms and cyanobacteria was measured using a Phyto-PAM (Walz, Germany) and number of cells per algal group was determined using a Coulter Elite flow cytometer. For quantifying pelagic zooplankton, $4 \mathrm{~L}$ of field sample was filtered $(33 \mu \mathrm{m}$; micro- and meso zooplankton), the residue was dissolved in $50 \mathrm{~mL}$ tap water, fixed with glutaraldehyde-formaldehyde (1\% solution) and stored cold and dark. Later, zooplankton was counted microscopically $(250 \times)$ using the sub sampling method of Kott (1953). Macrophytes abundance was obtained by monitoring species composition and percentage of surface cover in all three sites (source; bureau Waardenburg). Macrophytes were not sampled and analysed for stable isotope composition. Therefore a more detailed explanation of their role in carbon isotope dynamics was not feasible.

\subsection{Stable isotope analysis}

Concentrations and $\delta^{13} \mathrm{C}$ values $\left({ }^{13} \mathrm{C}:{ }^{12} \mathrm{C}\right.$ ratio) of DIC $(\mathrm{C}$ source used by algae for primary production) were measured every other week by injecting $1.5 \mathrm{~mL}$ of lake water into $8 \mathrm{~mL}$ airtight bottles that had been previously flushed with helium. To convert all DIC to $\mathrm{CO}_{2}$ the samples were acidified with $0.2 \mathrm{~mL} \mathrm{H}_{3} \mathrm{PO}_{4}(2 \mathrm{M})$ and after $24 \mathrm{~h}, 0.4 \mathrm{~mL}$ of the gaseous headspace was manually injected into a Euro Elemental Analyzer (Eurovector, Italy) coupled to a Finnigan Delta-S IRMS. A carbonate calibration series was run together with the samples $\left(10,20\right.$ and $40 \mathrm{ppm} \mathrm{Na}_{2} \mathrm{CO}_{3}$ in milli$\mathrm{Q}$, acidified and equilibrated similarly as the lake samples). Next, $\mathrm{CO}_{2(a q)}$ and $\mathrm{pCO}_{2}$ (ppmv) were derived from DIC and the in situ lake $\mathrm{pH}$ using $\mathrm{pK}$ values calculated according to Prieto and Millero (2002). Corrections for the discrimination of the heavy ${ }^{13} \mathrm{C}$ isotope (i.e. fractionation or $\varepsilon$ ), due to $\mathrm{CO}_{2}$ solubility, temperature and gas/sample volumes were made 
according to Baird et al. (2001), Miyajima et al. (1995) and Mook et al. (1974).

In addition $\delta^{13} \mathrm{C}$ values of cellular fatty acids (FA) of the various phytoplankton groups (cyanobacteria, eukaryotes (green algae + diatoms)) and zooplankton species were monitored at regular intervals, at the locations $-\mathrm{FW},-\mathrm{W}$ and $\mathrm{R}$. Preparation and analysis of the phytoplankton samples occurred by cell sorting on a flow cytometer followed by isotope measurements of group-specific FA as described in Pel et al. (2004a). In the isotope analyses for diatoms we focused on the $\mathrm{C}_{20: 5}$ FA (Middelburg et al., 2000), whilst for green algae, cyanobacteria, Microcystis and flab (floating algal beds) we used the $\mathrm{C}_{18: n}$ FA. At low algal densities, lake samples were concentrated by centrifugation (Jouan instruments, France) prior to cell sorting by flow cytometer (FACS). Pilot tests showed that cells remained intact and fluorescence was not significantly affected when centrifuged for $2 \times 10 \mathrm{~min}$., at 196 G. Microcystis and filamentous macroalgae (flab) were not sorted on the flow cytometer, but colonies and filaments were handpicked under a microscope. Zooplankton used for isotope analysis was concentrated by filtering lake water over a 33 micrometer filter and selecting the species under a stereomicroscope (magnification 10×). Depending on size and FA concentration of the different zooplankton species, 1 to 20 individuals were used per sample. The entire sample was pyrolised, but for isotope analyses of zooplankton we only focussed on the $\mathrm{C}_{18: n} \mathrm{FA}$.

Isotope analysis of FA was performed by in-situ pyrolytic methylation and IRMS linked gas chromatography. Instead of TMPAH (trimethyl phenyl ammonium hydroxide) as derivatisation reagent (Pel et al., 2003, 2004a), we used 0.5-0.7 microlitre TMSH (trimethyl sulfonium hydroxide; $0.25 \mathrm{M}$ solution in methanol) in the present study, because of the much reduced isomerization sideeffects of this reagent in the transesterification of polyunsaturated FA (Blokker et al., 2002). Carbon isotopic composition of the FA is reported in $\delta$-notation: $\delta^{13} \mathrm{C}$ in parts per thousand $(\% o)=\left[\left({ }^{13} \mathrm{C} /{ }^{12} \mathrm{C}_{\text {sample }}-{ }^{13} \mathrm{C} /{ }^{12} \mathrm{C}_{\text {reference }}\right)\right.$ 1] $\times 10^{3}$ expressed relative to Vienna Pee Dee Belemnite. Reproducibility was $<0.4 \%$ o for FCM-sorted phytoplankton and $\leq 0.3 \%$ for handpicked zooplankton (Pel et al., 2003). FA were identified by their retention times using a known sample of Limnothrix sp. strain MR1 (Pel et al., 2004a). As potential end members of the carbon sources of the pelagic food web in Terra Nova, we used the main primary producers (eukaryotes, cyanobacteria and macroalgae).

Isotope discrimination by the different phytoplankton groups, with respect to the $\mathrm{CO}_{2(a q)}$ source, will be expressed in terms of epsilon $(\varepsilon)$ calculated according to Freeman and Hayes (1992): $\quad \varepsilon=\left(\delta^{13} \mathrm{C} \mathrm{CO}_{2(a q)}-\delta^{13} \mathrm{C}_{\text {algae }}\right) /\left(1+\left(\delta^{13} \mathrm{C}\right.\right.$ $\left.\mathrm{CO}_{2(a q)} / 1000\right)$ ). In the calculation of the isotope fractionation of the phytoplankton groups, we corrected phytoplankton $\delta^{13} \mathrm{C}$ values for an offset of $9 \%$ o between FA and cell carbon biomass (see Pel et al., 2004a). The offset was used only in calculating the $\varepsilon$ in phytoplankton (Tables $3 \mathrm{a}, \mathrm{b}$ and c). All figures are based on raw $\delta^{13} \mathrm{C}$ values because comparisons are only made among $\mathrm{FA} \delta^{13} \mathrm{C}$ values.

\subsection{Growth rate measurements}

In order to relate phytoplankton population dynamics to group-specific isotopic signatures, in-situ specific growth rates $\left(\mu_{c}\left(\mathrm{~d}^{-1}\right)\right.$, where $\mathrm{c}$ is carbon) of cyanobacteria, green algae and diatoms for the 3 sites of Terra Nova were obtained monthly from 31 March till 25 November 2003. The growth rates were estimated from the rate of ${ }^{13} \mathrm{C}_{-} \mathrm{CO}_{2}$ incorporation into the FA over a $24 \mathrm{~h}$-period using the method of Pel et al. (2004b). To approach the in situ light conditions, the cells were exposed to the average light dose they received in the field (PAR), calculated according to Scheffer (1998), using Secchi depth, mixing depth and average light intensity of the previous 10 days. Light was provided by 4 to 8 Philips fluorescent light tubes (24W/840). Samples for obtaining growth rate were taken at $\mathrm{t}_{0 \mathrm{~h}}$ and $\mathrm{t}_{24 \mathrm{~h}}$ after enrichment and isotope analysis of the DIC and phytoplankton was performed as described above (sorted by FACS and isotopic composition measured by Py-GC-IRMS). Growth rates were calculated according to Welschmeyer and Lorenzen (1984). Because sample preparation for isotope analysis was labour intensive and GC analysis time relatively long, samples were analyzed in single.

\subsection{Statistical analysis}

Differences in the isotopic signatures of the main plankton groups, within and between treatments, were analyzed for significance using a repeated measurement ANOVA $(\mathrm{p}<0.05)$ using Statistica ${ }^{\circledR}$ (Stat Soft, Inc., U.S., 2003). Prior to analysis, data were checked for normality and homogeneity of variance. Statistical power was rather low because of large temporal variation in isotope data, lack of overlap between treatments and lack of replication. Simple isotope mass balances were used to estimate the dependence of zooplankton on prokaryotic and eukaryotic carbon resources.

\section{Results}

\subsection{General observations on the effects of biomanipulation}

Biomanipulation and wind reduction in Terra Nova had large effects on biotic and abiotic characteristics (Table 1). During the algal growing season, turbidities and phytoplankton densities (Chl. $a$ ) were lowest in - FW, intermediate in - W and highest in R (Fig. 2a and Table 1). In - FW, light penetrated to the sediment for most of the year, whilst in - W bottom visibility were never attained (Fig. $2 \mathrm{a}$ ). In $-\mathrm{W}$ and $\mathrm{R}$ phytoplankton biomass was dominated by filamentous or coccoid cyanobacteria (Planktothrix, Microcystis) with some contributions from green algae (e.g. Chlorococcales) and diatoms 


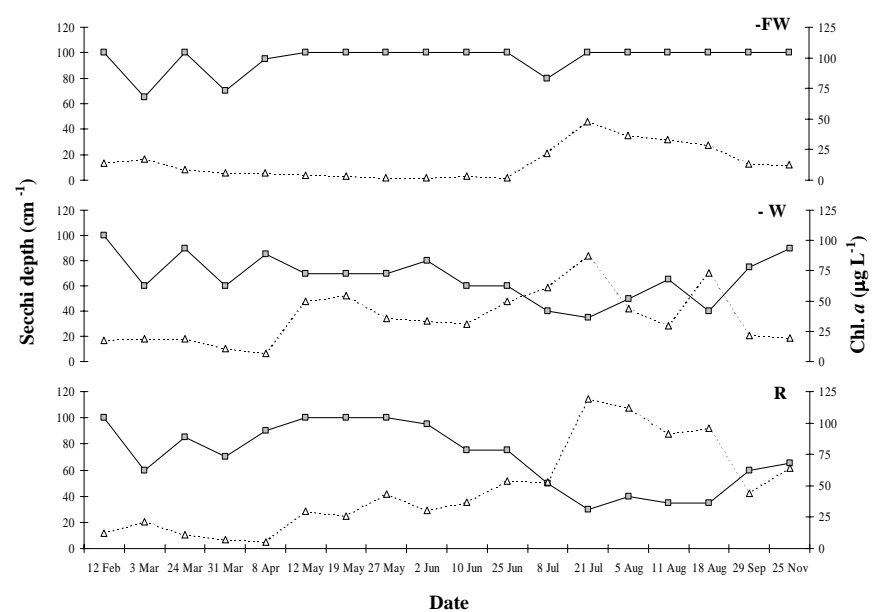

(a)

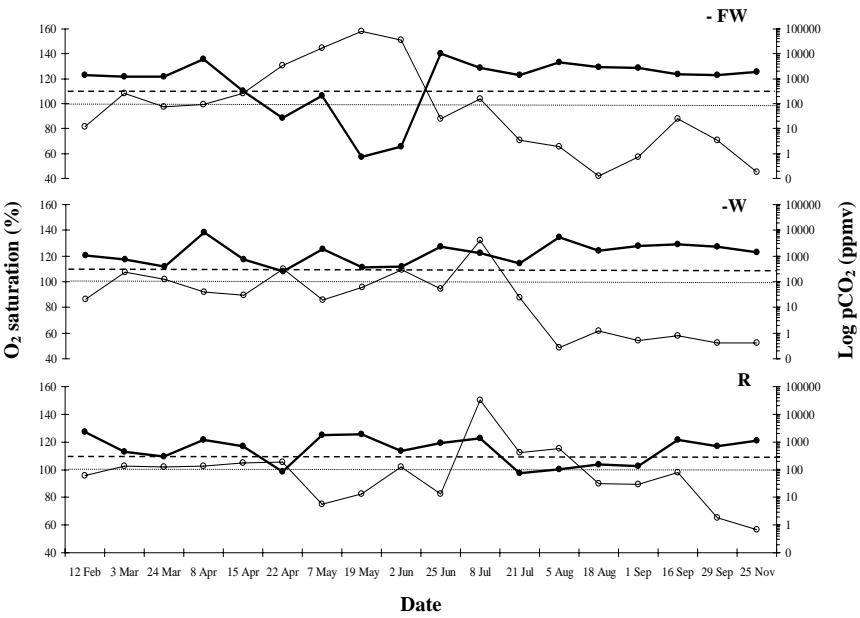

(b)

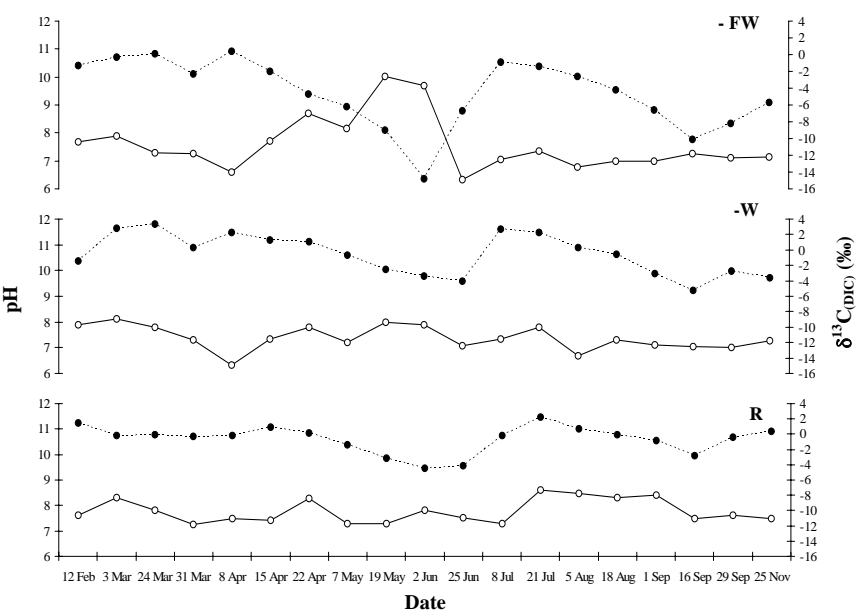

(c)

Fig. 2. In the three treatments - FW, - W and R at Terra Nova from 12 February-25 November 2003 (a) transparency as Secchi depth (filled squares) and algal biomass as total Chl. $a\left(\mu \mathrm{g} \mathrm{L}^{-1}\right)$ (open triangles) The sum of Chl. $a$ includes all algae groups present. (b) $\mathrm{O}_{2}$ (thin line with open symbols) and $\mathrm{CO}_{2}$ (heavy line with solid symbols) percentage in the water column. Net autotrophy is indicated by levels higher than by $100 \% \mathrm{O}_{2}$ saturation (thin horizontal line) and by $\mathrm{CO}_{2}$ levels lower than $\sim 370 \mathrm{ppmv}$ ) (dashed horizontal line) (c) $\mathrm{pH}$ (open circles, solid line) and stable isotope $\left(\delta^{13} \mathrm{C}\right)$ values of dissolved inorganic carbon (DIC) (solid circles, dotted line).

(Fragilara). In - FW the low algal biomass was equally divided over cryptophytes, flagellates, larger diatoms (Asterionella) and green algal species (Tetrastrum, Pediastrum), whereas cyanobacteria only played a minor role. Finally, in all locations extremely high numbers of small unicellular green algae were present. Nutrient levels and temperature, did vary in time, but did not vary significantly between treatments (Table 1).

Macrophyte monitoring (source bureau Waardenburg) revealed that treatment - FW was covered for $\sim 25 \%$ by macroalgae (Melosira, Ulothrix and Spyrogyra) and for $\sim 25 \%$ by floating macrophytes (Nymphae and Nuphar) (from 8 April to 23 July). The largest coverage of flab (40\%) occurred from 7 May to 16 June. By the end of August 95\% of - FW was covered by submerged macrophytes (Ceratophyllum and Elodea) and regularly seedlings of some rare species (e.g. Chara globularis, Nitella flexilis, Najas marina and Stratiotes aloides) were encountered in - FW. In - W, the cover of the lake by macroalgae also increased to $25 \%$, but during a shorter period (12-19 May). However, for the rest of the year submerged and floating macrophytes (Nymphae and Nuphar) covered $\sim 30 \%$ of the lake surface while Elodea and Ceratophyllum biomass remained low compared to - FW. In $\mathrm{R}$, macroalgae and submerged plants were almost absent and the site was dominated by the floating macrophytes Nymphae and Nuphar.

The total mean zooplankton density was more than twice as high in the presence of fish (-W and R) than in - FW (Table 2a). Mean zooplankton densities per month were highest in - W except in July, September and November when zooplankton was most abundant in $\mathrm{R}$ (Table $2 \mathrm{~b}$ ). The annual data show that small rotifers such as Keratella, Polyarthra, 
Table 2. Zooplankton densities at the 3 locations during 2003. (a) Annual mean zooplankton densities (ind. $\mathrm{L}^{-1}$ ) per group and per key species. Cladocera include the species Bosmina and Daphnia. Rotifers include species from the genus Keratella, Filinia, Polyarthra and Trichocerca. Cyclopoid nauplli and adult cyclopoids are considered separately, because of their different diet; (b) Mean dominant zooplankton species density per month (ind. $\mathrm{L}^{-1}$ ).

\begin{tabular}{|c|c|c|c|}
\hline & $-\mathrm{FW}$ & $-\mathrm{W}$ & $\mathrm{R}$ \\
\hline Total zooplankton & 1488 & 3723 & 3613 \\
\hline Cladocera & 109 & 377 & 149 \\
\hline Cyclopoida & 173 & 225 & 148 \\
\hline Nauplii & 419 & 627 & 506 \\
\hline Rotifera & 787 & 2494 & 2810 \\
\hline Bosmina & 48 & 304 & 88 \\
\hline Ceriodaphnia & 50 & 41 & 33 \\
\hline Chydorus & 4 & 18 & 16 \\
\hline D. cuculata & 2 & 12 & 10 \\
\hline Asplanchna & 52 & 172 & 56 \\
\hline Polyphemus & 5 & 0.4 & 0.9 \\
\hline \multicolumn{4}{|l|}{ (b) } \\
\hline & $-\mathrm{FW}$ & $-\mathrm{W}$ & $\mathrm{R}$ \\
\hline Feb & 391 & 624 & 273 \\
\hline March & 589 & 834 & 725 \\
\hline April & 884 & 1883 & 1696 \\
\hline May & 657 & 1490 & 922 \\
\hline June & 964 & 2387 & 2277 \\
\hline July & 1591 & 1338 & 3171 \\
\hline Aug & 721 & 2528 & 1346 \\
\hline Sep & 370 & 2604 & 3168 \\
\hline Nov & 248 & 715 & 3050 \\
\hline
\end{tabular}

Anuraeopsis and Trichocerca outnumbered all other species in all treatments, making up 53, 67 and $78 \%$ of the total annual zooplankton number in - FW, $-\mathrm{W}$ and $\mathrm{R}$, respectively (Table 2a). However, the relative contribution of cladocerans, cyclopoids and nauplii and some species of crustaceans (Polyphemus, Ceriodaphnia) was larger in - FW, though Bosmina and Asplanchna contributed relatively similar to the total of zooplankton in all treatments. In the period from 2000 to 2002, before the onset of the biomanipulation (Appendix A, Fig. A1c), rotifers in R contributed on average 72, 91 and $88 \%$ to total zooplankton. Furthermore, in 2002 crustaceans, copepods and nauplii contributed only 1,2 and 9\%, respectively.

\section{$3.2 \mathrm{pH}, \mathrm{O}_{2}$ and $\mathrm{CO}_{2}$ dynamics}

The effects of fish removal and the resulting extensive growth of macrophytes on $\mathrm{pCO}_{2}, \mathrm{O}_{2}$ saturation and $\mathrm{pH}$ in the water column were far-reaching (Fig. 2b and c). In - FW, pH in- creased from $\mathrm{pH} 7$ to 8.5 between 15 April and 7 May, followed by a second, equally large increase from $\mathrm{pH} 8.5$ to 10 within a two week period later in May (Fig. 2c). This high $\mathrm{pH}$ situation lasted until 2 June, after which $\mathrm{pH}$ went down again to $\approx 7$. Although no isotope data of macrophytes were available, these high $\mathrm{pH}$ values in - FW co-occurred with substantial increases in submerged macrophyte and macroalgal biomass and $\mathrm{O}_{2}$ and decreases in $\mathrm{pCO}_{2}$ (Fig. 2b). It appeared that in $-\mathrm{FW}$, between 15 April and 2 June, production outbalanced respiration and the system was periodically net autotrophic (Fig. 2b). This is indicated by $\mathrm{O}_{2(a q)}$ surpassing the $100 \%$ saturation level and $\mathrm{pCO}_{2}$ remaining below atmospheric levels $\left(<370\right.$ ppmv) (Fig. 2b). Lower $\mathrm{O}_{2}$ levels at the end of August may indicate increased mineralization of the macrophyte biomass and flab by bacteria and heterotrophic biota (Fig. 2b). Unfortunately this can not be confirmed by an increase in DOC or bacterial abundance because these parameters were not studied. In the treatments $-\mathrm{W}$ and $\mathrm{R}$, $\mathrm{pH}$ never exceeded 8.6, and values averaged around $\approx \mathrm{pH} 7$ throughout the year (Fig. 2c). It seems that $\mathrm{CO}_{2}$ production and $\mathrm{O}_{2}$ consumption (net heterotrophy) were the dominant processes directing the carbon fluxes in $-\mathrm{W}$ and $\mathrm{R}$ (Fig. 2b), although primary production increased during a short period (25 June-8 August 2003), shown as crossing the $\mathrm{O}_{2}$ saturation and $\mathrm{CO}_{2}$ depletion lines during that period.

\subsection{Stable isotope analysis of DIC, phytoplankton and zoo- plankton}

In - FW two large decreases in $\delta^{13} \mathrm{C}_{\mathrm{DIC}}$ were observed; from 8 April to 2 June (from $\approx 0 \%$ o to $-15 \%$ ) and from 21 July to 16 September (from $-1 \%$ o to $-10 \%$ ) (Fig. 2c; Tables B1a-c in Appendix B). These low $\delta^{13} \mathrm{C}$ values occurred only in the absence of fish and reduction of wind, because $\delta^{13} \mathrm{C}_{\text {DIC }}$ ranged from $\approx 2 \%$ o to $-4 \%$ o in the treatments $-\mathrm{W}$ and R (Fig. 2c). Furthermore, average seasonal $\delta^{13} \mathrm{C}$ values of DIC (mean -5.1\%o) were more depleted in - FW than $\mathrm{W}$ and $\mathrm{R}$ (mean $-1 \%$; Table B1a-c in Appendix B). The decrease in $\delta^{13} \mathrm{C}_{\mathrm{DIC}}$ observed in - FW during the autotrophic period, was contrary to what we expected, namely enrichment in ${ }^{13} \mathrm{C}_{\mathrm{DIC}}$ during periods of high primary production caused by the preferential use of ${ }^{12} \mathrm{C}$ during photosynthesis. The isotope signature of diatoms, green algae and cyanobacteria in - FW, $-\mathrm{W}$ and $\mathrm{R}$ did not significantly differ from each-other within or between treatments (ANOVA, $\mathrm{p}>0.05$ ) (Fig. 3a and Appendix B), but the $\delta^{13} \mathrm{C}$ of flab differed significantly $(\mathrm{p}<0.05)$ from the $\delta^{13} \mathrm{C}$ of diatoms and green algae in - FW and $-\mathrm{W}$ and as well from cyanobacteria and Microcystis in - W. Moreover, $\delta^{13} \mathrm{C}$ of Microcystis significantly differed from other cyanobacteria in R. In - FW and - W mean $\delta^{13} \mathrm{C}$ of eukaryotic algae (range; $-39.9 \%$ to $-44.4 \%$ ) were more depleted than cyanobacteria (range; $-33.4 \%$ to $-36.0 \%$ ) and Microcystis in - W $(-35.7 \%$ ) while flab was most enriched (range; $-22.7 \%$ o to $-27.3 \%$ ) (Fig. 3a). However, in $\mathrm{R}$ mean $\delta^{13} \mathrm{C}$ of eukaryotic algae and cyanobacteria 
Table 3. Temporal variation (12 February-25 November 2003) in the atmospheric pressure of $\mathrm{CO}_{2}(a q)$ (ppmv) per treatment and the fractionation $(\varepsilon)$ of the $\mathrm{C}_{20: 5}$ FA in diatoms and $\mathrm{C}_{18: n}$ FA in green algae, cyanobacteria, Microcystis and flab. Epsilons were calculated with $\mathrm{CO}_{2(a q)}$ as carbon source and corrected for the $\delta^{13} \mathrm{C}-\mathrm{CO}_{2(a q)}$ at the same date as the $\delta^{13} \mathrm{C}$ measurements of the algae.

\begin{tabular}{|c|c|c|c|c|c|c|c|c|c|c|c|c|c|c|c|c|}
\hline \multicolumn{6}{|l|}{$-\mathrm{FW}$} & \multicolumn{6}{|l|}{$-\mathrm{W}$} & \multicolumn{5}{|l|}{$\mathrm{R}$} \\
\hline & $\begin{array}{l}\mathrm{CO}_{2(a q)} \\
(\mathrm{ppmv})\end{array}$ & Diatoms & $\begin{array}{l}\text { Green } \\
\text { algae }\end{array}$ & $\begin{array}{l}\text { Cyano } \\
\text { bacteria }\end{array}$ & Flab & $\begin{array}{l}\mathrm{CO}_{2(a q)} \\
(\mathrm{ppmv})\end{array}$ & Diatoms & $\begin{array}{l}\text { Green } \\
\text { algae }\end{array}$ & $\begin{array}{l}\text { Cyano } \\
\text { bacteria }\end{array}$ & $\begin{array}{l}\text { Micro } \\
\text { cystis }\end{array}$ & Flab & $\begin{array}{l}\mathrm{CO}_{2(a q)} \\
(\mathrm{ppmv})\end{array}$ & Diatoms & $\begin{array}{l}\text { Green } \\
\text { algae }\end{array}$ & $\begin{array}{l}\text { Cyano } \\
\text { bacteria }\end{array}$ & $\begin{array}{l}\text { Micro } \\
\text { cystis }\end{array}$ \\
\hline 12-Feb & & & & & & 1069.0 & 16.0 & 23.2 & & & & & 33.97 & 32.87 & & \\
\hline 3-March & 1246.3 & 29.6 & 25.1 & & & 756.9 & 32.7 & 27.6 & & & & 435.9 & & & & \\
\hline 24-March & 1232.6 & 28.7 & 25.6 & & & 390.7 & 25.2 & 21.7 & & & & 289.9 & 28.95 & 24.29 & 26.51 & \\
\hline 22-April & 27.0 & 20.0 & 17.8 & & & 255.5 & 27.4 & 23.7 & & & & 85.8 & 20.95 & 18.98 & & \\
\hline 7-May & 209.4 & 24.7 & 20.4 & & & 1889.0 & 23.0 & 17.1 & & 17.6 & & & & & & \\
\hline 19-May & 0.7 & & 7.5 & 0.8 & & 355.4 & & & 15.6 & & & 1883.5 & 35.95 & 28.06 & 18.18 & \\
\hline 25-June & 10152.3 & 27.7 & 24.1 & & & 2280.3 & & & & & 0.4 & 939.5 & 12.40 & 14.34 & 12.90 & \\
\hline 8-July & 2658.2 & 25.0 & 26.8 & 22.3 & & 1288.7 & 16.7 & 19.4 & 12.0 & 13.2 & & 1368.1 & 15.83 & 20.88 & 25.04 & 18.94 \\
\hline 5-Aug & 4507.4 & 19.2 & 20.3 & 13.9 & 5.3 & 5515.4 & 25.5 & 24.6 & 22.4 & 20.6 & 7.8 & 101.1 & 14.99 & 14.41 & 18.78 & 16.43 \\
\hline 1-Sep & 2704.8 & 14.7 & 19.0 & & & 2461.9 & & 21.2 & 18.0 & 17.8 & 8.3 & 132.2 & & 14.33 & 20.05 & 13.01 \\
\hline 29-Sep & 1426.1 & & & & 6.4 & 2283.7 & 22.6 & 20.7 & 15.9 & 17.4 & & 707.4 & & 16.23 & 21.00 & 14.91 \\
\hline $25-\mathrm{Nov}$ & 1925.3 & 25.5 & 20.4 & 11.6 & 0.3 & 1391.1 & & 19.2 & 13.5 & 18.9 & & 1116.6 & 20.56 & 18.51 & 24.00 & 15.79 \\
\hline Mean & & 23.9 & 20.7 & 12.2 & 4.0 & & 23.9 & 22.2 & 17.2 & 17.6 & 5.5 & & 22.9 & 20.3 & 20.8 & 15.8 \\
\hline SE & & 1.7 & 1.7 & 4.4 & 1.9 & & 1.7 & 0.9 & 1.6 & 1.0 & 2.6 & & 2.8 & 2.2 & 1.6 & 1.0 \\
\hline
\end{tabular}

Note: Epsilon values were corrected for the offset between FA and total cell carbon content, by adding $9 \%$ o to the $\delta^{13} \mathrm{C}$ values (according to Pel et al., 2004a).

fell in the same range $(-38.5 \%$ o to $-41.1 \%$ ) and Microcystis was similarly enriched $(-33.4 \%$ ) as in $-W$. Finally at all sites, mean $\delta^{13} \mathrm{C}$ of diatoms were usually more depleted (range; $-41.1 \%$ o to $-44.4 \%$ ) than green algae (range; $-38.5 \%$ o to -41.8\%o) (Table B1a-c in Appendix B).

Phytoplankton isotope fractionation factors $(\varepsilon)$ showed large variation in all treatments and during the season (Table 3). However, the mean fractionations for all primary producers in - FW followed the sequence diatoms $(23.9 \pm 1.7)>$ green algae $(20.7 \pm 1.7)>$ cyanobacteria $(12.2 \pm 4.4)>$ flab $(4.0 \pm 1.9)$. The same sequence was observed in the $-\mathrm{W}$ treatment with diatoms $(23.9 \pm 1.7)>$ green algae $(22.2 \pm 0.9)>$ cyanobacteria (17.2 \pm 1.6$)$ and Microcystis $(17.6 \pm 1.0)>$ flab (5.5 \pm 2.6$)$. Annual mean fractionation factors in $\mathrm{R}$ also followed a similar sequence with diatoms $(22.9 \pm 2.8)>$ green algae $(20.3 \pm 2.2)$ and cyanobacteria $(20.8 \pm 1.6)>$ Microcystis $(15.8 \pm 1.0)$. Average fractionation factors $(\varepsilon)$ in diatoms and green algae were rather constant between treatments, but a clear shift was detected in filamentous cyanobacteria with low values in $-\mathrm{FW}$ and higher values in the other two treatments possibly related to changes in dissolved inorganic carbon speciation. Despite these consistent average fractionation patterns across treatments, there were no correlations between dissolved inorganic carbon species $\left(\mathrm{CO}_{2}, \mathrm{HCO}_{3}^{-}\right.$, $\mathrm{CO}_{3}^{2}$ ) and phytoplankton fractionation factors $(\varepsilon)$.

Variation in isotope values of the zooplankton was large (Fig. 3b and Table B1a-c in Appendix B) and ANOVA revealed that zooplankton isotope signatures did not differ significantly within or between treatments. It is therefore difficult to conclude that specific algal groups supported the zooplankton diet. However, the isotope signatures of zooplankton clearly reveal that most, if not all species were gen- eralists and probably supported by a mixed diet. Simple isotope mass balance equation using prokaryotic and eukaryotic (average of green algae and diatoms) end member values (Fig. 3a) show that in - FW and $-\mathrm{W}$ zooplankton derived 64 and $69 \%$ of its carbon from eukaryotes, while in R prokaryote resources were more important (on average only $43 \%$ of the carbon was derived from eukaryotes).

\subsection{Phytoplankton growth rates}

Figure 4 shows that, irrespective of the treatment and time of year, specific growth rates of diatoms, green algae or cyanobacteria never exceeded $0.4 \mathrm{~d}^{-1}$. Highest growth rates of green algae $\left(0.33 \mathrm{~d}^{-1}\right)$ and diatoms $\left(0.15 \mathrm{~d}^{-1}\right)$ in $-\mathrm{FW}$ and of cyanobacteria $\left(0.19 \mathrm{~d}^{-1}\right)$ in $\mathrm{R}$ were achieved on 25 June 2003. Mean $\mu_{c}$ values indicate that green algae and diatoms were the dominant primary producers in - FW (boxes in Fig. 4), whilst cyanobacteria became more important as effects of fish and wind increased. Prior to increases in densities in cyanobacteria (Chl. $a$ ) in R they appeared to grow faster (25 June). Within the present data set, two growth peaks occur in - FW (31 March and 25 June) and in - W and R (7 May and 25 June). Unfortunately datasets of Chl. $a$ and $\mu_{c}$ were not completely overlapping, because algal densities were sometimes too low to sort the clusters by FACS and growth rates were obtained on a monthly basis only. Nevertheless, with exception of the high growth rate of green algae on 31 March in - FW, high growth rates were generally followed, though somewhat delayed, by increases in phytoplankton biomass (Chl. $a$ ). 
(a)

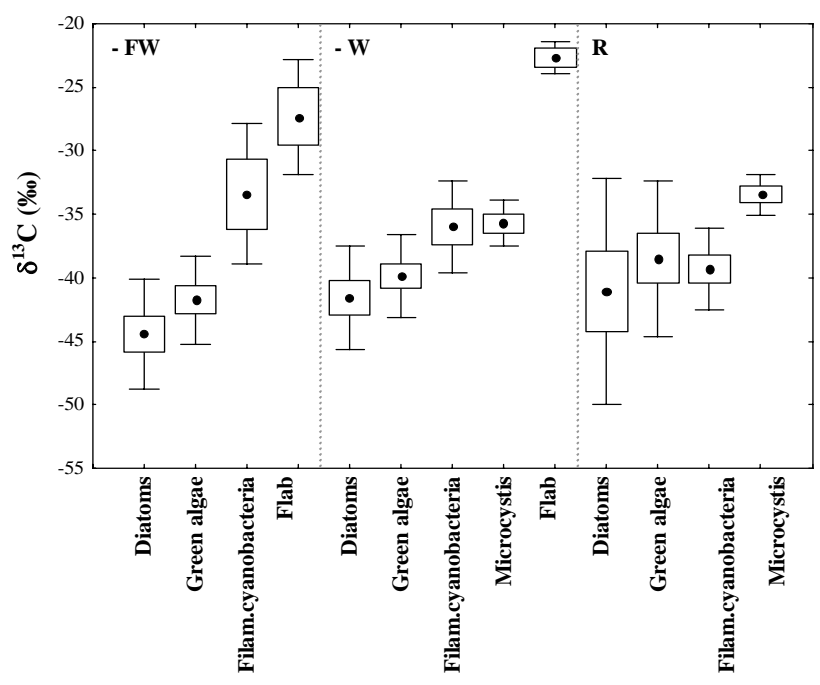

(b)

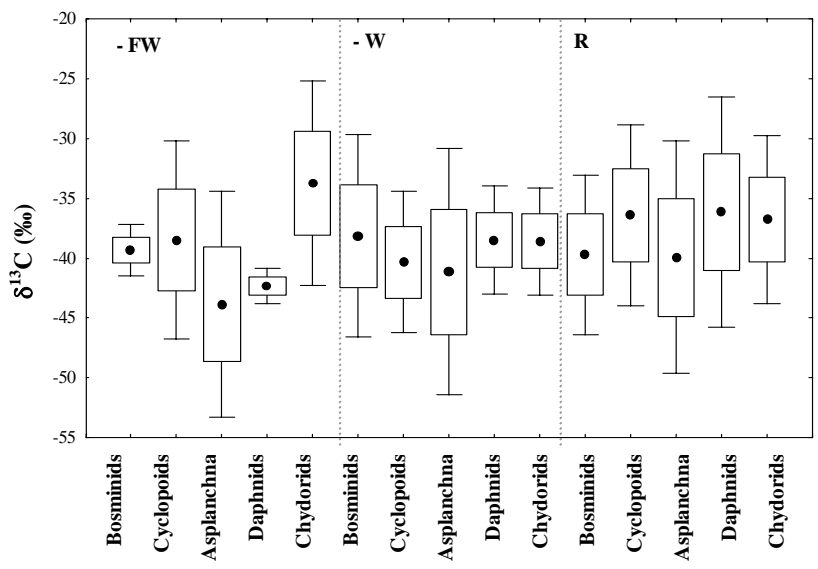

Fig. 3. Mean raw $\delta^{13} \mathrm{C}$ values (\%o) of (a) the main primary producers and (b) the most abundant primary consumers in the three treatments $-\mathrm{FW},-\mathrm{W}$ and $\mathrm{R}$ during 2003 in Terra Nova. Dots show mean $\delta^{13} \mathrm{C}$ values per functional group, boxes give the $95 \%$ confidence intervals and whiskers the standard deviation. The $\delta^{13} \mathrm{C}$ for all organisms is based on the $\mathrm{C}_{18: n} \mathrm{FA}$, but for diatoms on the $\mathrm{C}_{20: 5}$ FA.

Note: Filamentous cyanobacteria species such as Planktothrix and Limnothrix were separately analyzed from the cyanobacteria species Microcystis.

\section{Discussion}

Using a combination of fluorescence-activated cell sorting (FACS) and isotope ratio mass spectrometry (Py-GC-IRMS) we have identified differences in isotopic signatures of phytoplankton groups (Fig. 3a). These differences in isotopes signatures at the base of a lacustrine pelagic food web would in principle have allowed us to obtain detailed information on algal-herbivore food web interactions and the effect of biomanipulation on these relations. However, most of the examined consumers were generalists; i.e. most zooplankton appeared to rely on both prokaryotic and eukaryotic primary producers (Fig. 3b) and there were only minor differences in zooplankton resource utilisation between treatments. Before discussing in detail the isotope results, it is instructive to evaluate the biomanipulation results in general.

\subsection{The effect of biomanipulation on phytoplankton and} zooplankton

The decrease in turbidity and Chl. $a$ concentration as a result of the fish removal in - FW has been described in other biomanipulation studies (Gulati and Van Donk, 2002; Van Donk et al., 1994). The dominant filamentous cyanobacteria (e.g. Planktothrix) with a mean Chl. $a$ concentration of $60 \mu \mathrm{g}$ $\mathrm{L}^{-1}$ from 2000 to 2002 (Fig. A1b in Appendix A), almost entirely disappeared from - FW in 2003 (mean annual Chl. $a$ concentration $26 \mu \mathrm{g} \mathrm{L}^{-1}$ ), but biomass was never fully replaced by green algae and diatoms. Low algal biomass in FW can be attributed to a number of causes; (1) macrophytes may have outcompeted the algae for nutrients; (2) zooplankton, though present in low numbers, was still able to graze away the algae and (3) the algae may have settled to the bottom due to (near) absence of wind in - FW and - W. Moreover, net sedimentation losses were likely higher in - FW because resuspension of algae by fish was missing as well in this location. Large differences in cyanobacterial biomass between $-\mathrm{W}$ and $\mathrm{R}$, may be the result of a larger wind fetch in R (Van Donk et al., 1994), leading to sediment resuspension and high turbidities, thereby promoting low light adapted cyanobacterial growth (Chorus and Bartram, 1999). Although in - FW we expected an increase in abundance of large sized grazers in response to the absence of fish (Hosper, 1993), we observed only low numbers. We can only speculate about the causes; such as reduced reproduction and growth of daphnids due to low food availability (algae) or increased predation by planktivorous fish, still present in - FW. The latter explanation is less likely, because during the entire experimental period, fish densities were kept at a low level by regular fishing. Alternatively, the sensitivity of Daphnia to elevated pH levels (Steiner, 2004) may have prevented this species from growing well in - FW. The bulk of zooplankton biomass in all locations consisted of small rotifers (e.g. Keratella, Filinia, Polyarthra) accounting for 53, 67 and $78 \%$ of the total zooplankton abundance in - FW, - W and R, respectively. Our observations on zooplankton abundances evidently show that predation by fish on invertebrates is not the only factor determining whether a lake will be clear and dominated by plants or turbid and dominated by phytoplankton (Hosper, 1993; Van Donk et al., 1994). In FW, pelagic total phosphorous (TP) concentrations remained similar to those at the other locations, ranging from 0.05$0.2 \mathrm{mg} \mathrm{L}^{-1}$ (Table 1) (eutrophic - hypertrophic), but nevertheless clear water was achieved and macrophytes settled. 


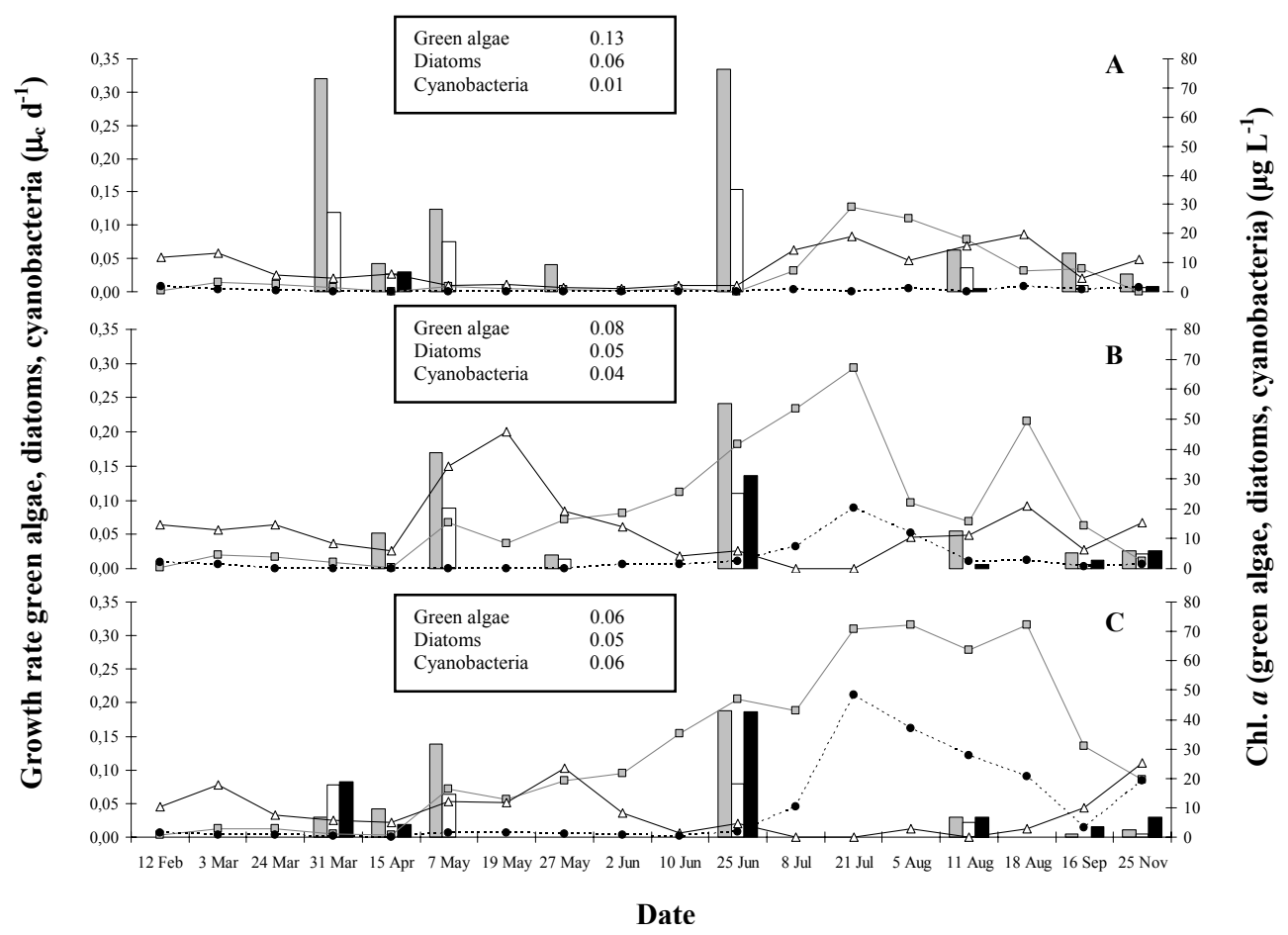

Fig. 4. Growth rates $\left(\mu_{C} \mathrm{~d}^{-1}\right)$ and abundances of green algae, diatoms and cyanobacteria $\left(\mu \mathrm{g}\right.$ Chl. $\left.a \mathrm{~L}^{-1}\right)$. Mean growth rates $\sim 18$ and $\sim 24 \mathrm{~h}$. after incubation are calculated as the ${ }^{13} \mathrm{C}$ incorporation into the $\mathrm{C}_{18: n} \mathrm{FA}$ of green algae (grey column) and cyanobacteria (black column) and $\mathrm{C}_{20: 5}$ FA of diatoms (white column). Abundances of the green algae, diatoms and cyanobacteria are given by; the grey line with squares, black line with triangles and dotted line with circles, respectively. Boxes represent the average seasonal growth rate $\left(\mu_{C} \mathrm{~d}^{-1}\right)$, per algal group, per treatment.

Evidently, nutrient reduction is just one of the key factors for (the initial) restoration to fail or to succeed. Scheffer (1998), Jeppesen et al. (1997) and Søndergaard et al. (2003) also reported that at comparable nutrient levels, shallow lakes may be either clear or turbid depending on biological feedbacks in the system. Most food-web interactions involved in these biological feedbacks are poorly understood and our detailed study of carbon cycling based on stable isotopes may provide some insights.

\subsection{Effect of biomanipulation on ecosystem metabolism and $\delta^{13} \mathrm{C}_{\mathrm{DIC}}$}

Fish removal in - FW resulted in enormous alterations in primary productivity and carbon cycling, raising the $\mathrm{O}_{2}$ and $\mathrm{pH}$ and lowering the $\mathrm{CO}_{2}$ level and the biomanipulated lake shifted towards a $\mathrm{CO}_{2}$ sink during some periods. Biomanipulation resulted in $\mathrm{pH}$ increases as high as 10.4 , while in the years prior to biomanipulation $\mathrm{pH}$ never exceeded 9 (20002002; Fig. A1a in Appendix A). This conspicuous response in $\mathrm{pH}$ in treatment - FW was accompanied by a large increase in $\mathrm{O}_{2}$ and a decrease in $\mathrm{CO}_{2}$. At the same time we observed depletion (more negative $\delta^{13} \mathrm{C}$ values) of the inorganic carbon source (DIC), while in treatments $-\mathrm{W}$ and $\mathrm{R}$ these parameters fluctuated less. Although heterotrophy dominated ecosystem metabolism in all three treatments for the most part of 2003, autotrophy clearly dominated during periods with high $\mathrm{pH}, \mathrm{O}_{2}$ and low $\mathrm{CO}_{2}$ in treatment $-\mathrm{FW}$ (between 22 April and 25 June). Schindler et al. (1997), Cole et al. (2000) and Carpenter et al. (2001) reported similar reductions in $\mathrm{CO}_{2}$ following biomanipulation although their study lakes were restocked with different species of fish or loaded with nutrients after removal of fish. Therefore, we may conclude that, also under the moderate to high TP conditions in Terra Nova, removal of fish temporarily changed the system to a net sink for atmospheric carbon, while under turbid, non-manipulated conditions the system was as a net source of carbon, consistent with observations by Cole et al. (2000).

Under high $\mathrm{pCO}_{2}$, heterotrophic conditions, $\delta^{13} \mathrm{C}_{\mathrm{DIC}}$ usually becomes lighter, because respiration adds $\delta^{13} \mathrm{C}$ depleted DIC (Goericke et al., 1994; Bade et al., 2004), while under low $\mathrm{pCO}_{2}$ conditions, as in $-\mathrm{FW}$, significant increases in $\delta^{13} \mathrm{C}_{\mathrm{DIC}}$ are expected. The reasoning for the anticipated increase in $\delta^{13} \mathrm{C}_{\mathrm{DIC}}$ is that during assimilation the (light) ${ }^{12} \mathrm{C}$ isotope will be preferentially incorporated by autotrophs over the (heavy) ${ }^{13} \mathrm{C}$ isotope and as a result the remaining small pool is enriched in ${ }^{13} \mathrm{C}$. However, two periods with decreases in $\delta^{13} \mathrm{C}_{\text {DIC }}$ at low $\mathrm{pCO}_{2}$ were observed (Fig. 2b and c) and we attribute these to an influx of $\mathrm{CO}_{2}$ from 
the atmosphere (Herczeg and Fairbanks, 1987). The high biomass of macroalgae and perhaps macrophytes in - FW between 8 April and 25 June, led to low $\mathrm{CO}_{2}$ concentrations, high $\mathrm{pH}$ levels and the potential for Chemically Enhanced Diffusion (CED) to take place (Bade and Cole, 2006; Wanninkhof and Knox, 1996; Herczeg and Fairbanks, 1987). During CED the reaction of atmospheric $\mathrm{CO}_{2}$ with high concentrations of dissolved $\mathrm{OH}^{-}$dominated in the reaction to $\mathrm{H}_{2} \mathrm{CO}_{3}$. This reaction with $\mathrm{OH}^{-}$is known to have a large negative fractionation $(\sim-15 \%$ o $)$ opposite to the fractionation observed during the reaction of $\mathrm{CO}_{2}$ with $\mathrm{H}_{2} \mathrm{O}(\sim+8 \%$ o $)$ (Craig, 1953; Peterson and Fry, 1987). In Peter Lake and other lakes found in literature sources, similar trends in negative $\delta^{13} \mathrm{C}_{\text {DIC }}$ values at high $\mathrm{pH}$ were described (Bade et al., 2004; Bade and Cole, 2006). During the second period of depletion of $\delta^{13} \mathrm{C}_{\text {DIC }}$ in - FW, we attribute this negative excursion to be a combined effect of CED (macrophytes cover $\sim 95 \%$ ) and respiration of detritus (rich in ${ }^{12} \mathrm{C}$ ). Higher water temperatures during that period (range $20-22^{\circ} \mathrm{C}$ ) may have increased respiration (Leggett et al., 1999; Rounick and Winterbourn, 1986; Rau, 1978), while at the same time a release of biogenic methane from the sediment (range - 40 to $60 \%$; Sierszen et al., 2004) may have depleted the DIC even further. Unfortunately, we have no data (increased bacterial abundance or DOC) to confirm or refute this.

\subsection{Carbon isotopes of phytoplankton groups}

The use of flow cytometric cell sorting combined with pyrolysis IRMS allowed us to detect differences between the isotopic signatures of the primary producers and different treatments (Fig. 3a). However, large temporal fluctuations complicated the overall picture and lowered the statistical significance. Flab $\delta^{13} \mathrm{C}$ was more enriched (positive) compared to diatoms and green algae in - FW and compared to all phytoplankton groups in - W (Fig. 3a). Diatoms were more depleted than green algae, which were in turn both more negative than cyanobacteria in $-\mathrm{FW}$ and $-\mathrm{W}$ (and Microcystis in $-\mathrm{W}$ ), but not in R (Table B1a, b, and c in Appendix B). Microcystis in $\mathrm{R}$ was heavier than the other phytoplankton groups. In contrast, Pel et al. (2003) found in the neighbouring Lake Loosdrecht that cyanobacteria were far more depleted than green algae and diatoms, while Boschker et al. (2005) found that diatoms were more enriched than green algae in the upper part of the Scheldt estuary. Since phytoplankton group-specific stable isotope signatures are not yet widely available for natural populations we do not know whether the variability observed in this study and between this study, Pel et al. (2003) and Boschker et al. (2005) is a general phenomena. Recently, Finlay (2004) reported significant seasonal and spatial variability in periphyton $\delta^{13} \mathrm{C}$ signatures in lotic ecosystems. Such variability complicates food-web studies based on stable isotope techniques and requires new research to identify and quantify the controlling factors.
The variation in $\delta^{13} \mathrm{C}$ signature of the algae, may be a consequence of several factors including: the inorganic carbon species taken up $\left(\mathrm{CO}_{2}, \mathrm{HCO}_{3}^{-}\right)$, concentration and $\delta^{13} \mathrm{C}$ value of the $\mathrm{C}$ source, the specific growth rate (function of temperature, light, nutrients), cell geometry (cell permeability, cell size), C uptake kinetics (diffusion vs. active uptake) and the photosynthetic pathway (Laws et al., 1995; Peterson and Fry, 1987). Isotope fractionation models consider $\mathrm{CO}_{2}$ as the substrate and predict a linear relationship between the ratio of growth rate $\left(\mu_{c}\right)$ and carbon dioxide concentration (Laws et al., 1995). Although correlations between $\varepsilon$ values on the one hand and $\mathrm{CO}_{2}$ (e.g. Finlay, 2004) or $\mu_{c} / \mathrm{CO}_{2}$ (e.g. Laws et al., 1995; Boschker et al., 2005) on the other hand have been reported, there are observations contradicting this (e.g. Laws et al., 1997; Keller and Morel, 1999). Correlation analysis of Terra Nova data (Table 3 ) revealed that there were no systematic relationships between $\varepsilon$ values and $\mathrm{CO}_{2}$.

Mean epsilons for diatoms (range 22.9-23.9) and green algae (range 20.3-22.2) were rather constant and independent of treatment $(-\mathrm{FW},-\mathrm{W}$ or $\mathrm{R})$ and/or growth rate, suggesting that the algae in these groups were fixing $\mathrm{CO}_{2}$, via the expected $\mathrm{C}_{3}$ photosynthetic pathway and representing fractionation via Rubisco ( $\varepsilon \approx 25-29 \%$; Goericke et al., 1994). The epsilon for flab (macroalgae), also based on the $\mathrm{C}_{18: n}$ $\mathrm{FA}$, was $\approx 4 \%$ o. This observation of very low fractionation is consistent with studies describing "boundary-layer diffusion resistance" in sedentary or benthic organisms. Under low turbulent conditions unstirred layers, enriched in ${ }^{13} \mathrm{C}$, form around the surface cells of sedentary organisms, forcing these cells to take up proportionally more ${ }^{13} \mathrm{C}$ than ${ }^{12} \mathrm{C}$ (LaZerte and Szalados, 1982; Goericke et al., 1994; France and Catanneo, 1998). On the contrary, mean $\varepsilon$ of cyanobacteria showed more variability between treatments; ranging from 12.2 to 17.2 to 20.8 from $-\mathrm{FW}$ to $\mathrm{R}$. These differences in isotope fractionation can be related to a number of factors. First, differences in growth rates of the cyanobacteria in the different locations might have caused differences in $\varepsilon$. However, we would then expect fractionation to decrease as growth rate increased, while the results showed that growth rates (Fig. 4) and $\varepsilon$ both increased from - FW $\left(\mu_{c}\left(\mathrm{~d}^{-1}\right)=0.01 ; 0.04\right.$ and 0.06 from $-\mathrm{FW}$ to $\left.\mathrm{R}\right)$. Second, differences in $\mathrm{CO}_{2}$ availability between $-\mathrm{FW},-\mathrm{W}$ and $\mathrm{R}$, may have played a significant part in the variance in $\varepsilon$ between the algal groups. While the eukaryotic algae fixed $\mathrm{CO}_{2}$ via the $\mathrm{C}_{3}$ pathway (Rubisco), cyanobacteria (Microcystis) might have additionally utilized bicarbonate via carboxylation with decreased fractionation. This fixation pathway is used by phototrophic organisms adapted to $\mathrm{CO}_{2}$ limitations, such as cyanobacteria, under $\mathrm{CO}_{2}$ limiting conditions (Goericke et al., 1994). And finally, the relative importance of $\mathrm{CO}_{2}$ uptake and active $\mathrm{HCO}_{3}^{-}$uptake by cyanobacteria, as a consequence of the differences in $\mathrm{CO}_{2}$ availability in the three different treatments $(-\mathrm{FW},-\mathrm{W}, \mathrm{R})$, may have determined the variance in $\varepsilon$ of the cyanobacteria (Cassar et al., 
2004; Keller and Morel, 1999). Assuming that the overall fractionation of cyanobacteria growing on $\mathrm{CO}_{2}$ would be the same as that of green algae and diatoms $(\sim 21 \%$ o $)$ and following the approach of Keller and Morel (1999) and Cassar et al. (2004), we propose the relation: $\varepsilon=21-21.3 *$ fa, where fa is the fraction of $\mathrm{HCO}_{3}^{-}$that is actively taken up and the dependency -21.3 comes from Eq. (8) of Cassar et al. (2004). If $\mathrm{fa}=0$, there is no active bicarbonate uptake and $\varepsilon=21$ due to passive $\mathrm{CO}_{2}$ uptake (like for diatoms and green algae). If $\mathrm{fa}>0$ then some bicarbonate is taken up actively. On the basis of this relationship we estimate that cyanobacteria actively took up $\sim 50 \%$ in $-\mathrm{FW}, \sim 25 \%$ in $-\mathrm{W}$ and nothing in $\mathrm{R}$. This $\mathrm{CO}_{2}$ availability dependence is rather uncertain, because it is based on marine phytoplankton (Phaedactylum tricornutum), and adopting another value (e.g. -10 rather -21.3) would change the actual estimate of active uptake, but not our conclusion that active uptake of bicarbonate by cyanobacteria under low $\mathrm{pCO}_{2}$ may explain our results.

\subsection{Carbon isotopes of zooplankton}

One of our aims was to determine whether fish removal would shift food preferences in zooplankton species. However variability in isotope signatures of zooplankton as well as phytoplankton was rather high, complicating the use of $\delta^{13} \mathrm{C}$ to resolve consumer diet sources, and therefore we mainly focussed on understanding the variation in the $\delta^{13} \mathrm{C}$ of the sources. Nonetheless some conclusions can be drawn from the consumer isotope results; except the enriched $\delta^{13} \mathrm{C}$ of Chydorus and depleted $\delta^{13} \mathrm{C}$ of Asplanchna in - FW, most consumers seemed generalists and isotope signatures largely overlapped between species and treatments. However, simple mass balance calculations indicate that zooplankton preferred eukaryotes over cyanobacteria in the lakes - FW and - W (64 and 69\% of its carbon came from eukaryotes), while in the reference area cyanobacteria accounted for more than $50 \%$ of the isotope signature of the zooplankton. In - FW, green algae grew faster than diatoms, which grew faster than cyanobacteria. Since this is not reflected in the biomass of the algal groups (Fig. 4), we attribute this to preferential grazing on green algae and small diatoms. The observed preference for eukaryotic algae by zooplankton is consistent with that reported by Pel et al. (2003). In Lake Loosdrecht they found that zooplankton largely relied on eukaryotic algae despite the abundance of cyanobacterial-derived carbon. Gulati and deMott (1997) also showed that diatoms and phytoflagellates formed high-quality food sources for various zooplankton. The relative enriched $\delta^{13} \mathrm{C}$ of Chydorus sp. might imply that this species may have grazed upon cyanobacteria, as did Euchlanis in Lake Loosdrecht (Pel et al., 2003). Alternatively, considering its semi-benthic habitat, Chydorus may have fed on an enriched food source near the bottom (benthic algae or epiphyton). The depleted $\delta^{13} \mathrm{C}$ value of the large rotifer Asplanchna, in - FW, might reflect a preference for the depleted green algae and diatoms, consistent with data on As- planchna and Brachionus in Pel et al. (2003). Alternatively, the depleted values of Asplanchna may be related to their exploitation of another food source such as $\mu$-algae (Pel et al., 2003), for which we do not have isotope data. However, considering the stable isotopic values and the abundance of algae, rotifers and copepods, we hypothesize that these very abundant small $(\mu)$ green algae may have formed an important food source for the small rotifers (e.g. Brachionus), which were subsequently preyed upon by the Asplanchna or copepods.

Although our study provides an unprecedented level of detail in the isotopic signatures of the primary producers, the food web structure became not completely clear. This is due to a number of factors, (1) the wide range and variability of primary producers $\delta^{13} \mathrm{C}$ values lowered the resolution, (2) multiple food substrates were consumed (omnivory) indicating that the food web was not structured in a linear fashion and generalist consumers prevailed (Kerner et al., 2004) and (3) some important food sources such as $\mu$-algae and heterotrophic bacteria have been overlooked.

\section{Summary and conclusions}

Biomanipulation of the shallow Terra Nova followed the expectations with respect to increases of transparency, macrophyte settlement and decreases in abundance of phytoplankton, but zooplankton numbers did not increase. Fish removal led, at least during late spring/early summer, to increased primary productivity which in turn caused low $\mathrm{CO}_{2}$, high $\mathrm{O}_{2}$ concentrations and anomalous negative $\delta^{13} \mathrm{C}_{\mathrm{DIC}}$ values due to chemical enhancement of $\mathrm{CO}_{2}$ diffusion at high $\mathrm{pH}$ levels. This seems a more general phenomenon at high levels of primary productivity, as it has been observed in the biomanipulated Peter Lake as well (Bade et al., 2004). Removal of fish resulted in enhanced growth of green algae and diatoms at the expense of cyanobacteria. Large variations in isotope values within and between the plankton species made it difficult to draw strong conclusions, but from differences in $\mathrm{CO}_{2}$ concentrations and mean fractionation data of the different primary producers in the three treatments it appeared that at least in - FW and $-\mathrm{W}$, green algae and diatoms fixed $\mathrm{CO}_{2}$, while cyanobacteria might take up $\mathrm{HCO}_{3}^{-}$. Finally, although detailed isotopic values for phytoplankton and zooplankton were obtained by combining FACS and IRMS (Appendix B), this was not sufficient to identify which primary producers were fuelling the primary consumers. Zooplankton, except Asplanchna, appeared all generalists in Lake Terra Nova. To more thoroughly unravel relations in the lower part of food webs we suggest the use of additional analytical tools, for instance additional isotopes such as ${ }^{15} \mathrm{~N}$ (Veuger et al., 2005) or a combination of tracer experiments with numerical models (Pace et al., 2004; Van den Meersche et al., 2004). 


\section{Appendix A}

(a)

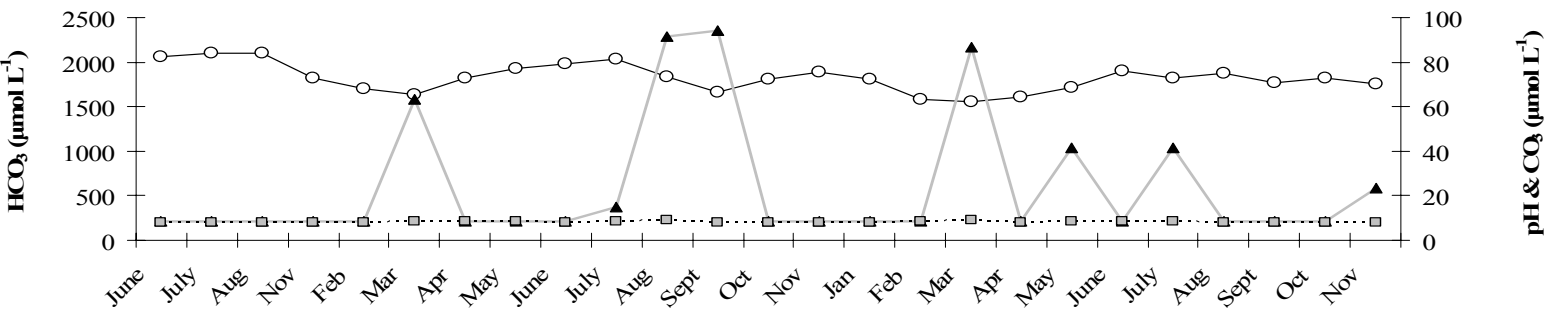

(b)

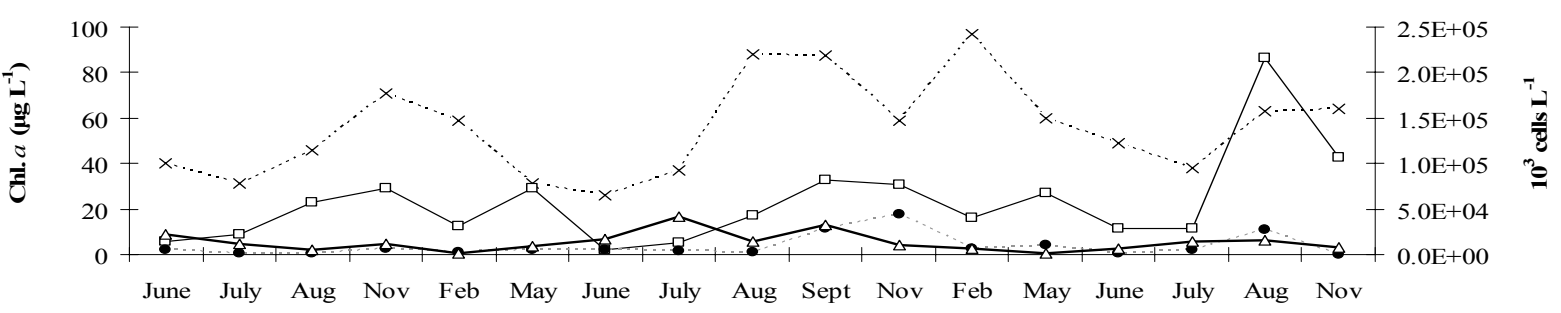

(c)

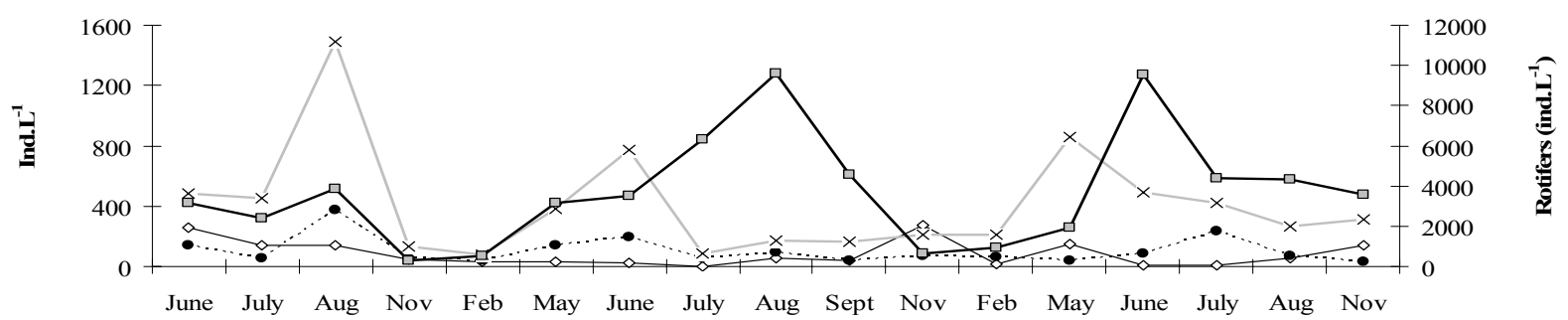

Fig. A1. Abiotic and biotic parameters measured in the reference area (R) of Terra Nova, 3 years prior to biomanipulation (a) pH (squares), $\mathrm{HCO}_{3}$ (circles) and $\mathrm{CO}_{3}$ (triangles) concentrations $\left(\mu \mathrm{mol} \mathrm{L}{ }^{-1}\right)$; (b) Chl. $a\left(\mu \mathrm{g} \mathrm{L}^{-1}\right)$ (crosses) and concentrations $\left(10^{3}\right.$ cells $\left.\mathrm{L}^{-1}\right)$ of diatoms (circles), green algae (triangles) and cyanobacteria (squares) (c) densities of rotifers (squares; scaled on the right y-axis), nauplii larvae (crosses), copepods (circles) and crustaceans (diamonds) scaled on the left y-axis (ind. $\mathrm{L}^{-1}$ ). 


\section{Appendix B}

Table B1. Temporal variation in the raw $\delta^{13} \mathrm{C}$ values (\%o) of the $\mathrm{C}_{18: n}$ FA value for green algae, cyanobacteria (Microcystis), flab and all assessed zooplankton species and the $\mathrm{C}_{20: 5}$ FA for diatoms in (a) - FW (b) - W and (c) R and the $\delta^{13} \mathrm{C}$ of the $\mathrm{CO}_{2(a q)}$ source.

\begin{tabular}{|c|c|c|c|c|c|c|c|c|c|c|c|c|}
\hline Date & Diatoms & $\begin{array}{l}\text { Green- } \\
\text { algae }\end{array}$ & $\begin{array}{l}\text { Cyano- } \\
\text { bacteria }\end{array}$ & $\begin{array}{l}\text { Micro- } \\
\text { cystis }\end{array}$ & Flab & Bosmina & Cyclopoids & Asplanchna & Daphnids & Chydorids & $\begin{array}{l}\mathrm{CO} 2 \\
\text { (aq) }\end{array}$ & DIC \\
\hline 12-Feb & & & & & & & -47.2 & -48.3 & & & -9.9 & -1.3 \\
\hline 3-March & -47.7 & -43.1 & & & & -39.8 & -38.4 & & & & -9.0 & -0.3 \\
\hline 24-March & -45.8 & -42.7 & & & & & & & -41.8 & & -8.1 & 0.1 \\
\hline 22-April & -42.4 & -40.2 & & & & -37.7 & & -38.0 & & -34.6 & -13.4 & -4.7 \\
\hline 7-May & -48.7 & -44.4 & & & & & & & & & -14.9 & -6.2 \\
\hline 19-May & & -33.3 & -26.6 & & & & -33.8 & & & & -16.8 & -9.0 \\
\hline 2-June & & & & & -30.9 & & -39.5 & & & -27.9 & -22.6 & -14.8 \\
\hline 25-June & -48.8 & -45.2 & & & & & -38.7 & -40.6 & & -38.5 & -12.0 & -6.7 \\
\hline 8-July & -42.8 & -44.6 & -40.1 & & & & -36.3 & -43.1 & -42.9 & & -8.8 & -0.9 \\
\hline 5-Aug & -38.0 & -39.2 & -32.8 & & -24.2 & -40.0 & -40.9 & & & & -9.8 & -2.6 \\
\hline $1-$ Sep & -38.0 & -42.3 & & & & & -40.5 & & & -34.0 & -14.3 & -6.6 \\
\hline 29-Sep & & & & & -31.5 & & -31.6 & & & & -16.0 & -8.2 \\
\hline 25-Nov & -47.9 & -42.8 & -34.1 & & -22.7 & -39.8 & -37.9 & -49.1 & & & -13.4 & -5.7 \\
\hline Mean & -44.4 & -41.8 & -33.4 & & -27.3 & -39.3 & -38.5 & -43.8 & -42.3 & -33.7 & -13.0 & -5.1 \\
\hline SE & 1.4 & 1.1 & 2.8 & & 3.8 & 0.5 & 1.3 & 2.2 & 0.5 & 2.2 & 1.1 & 1.2 \\
\hline \multicolumn{13}{|l|}{ (b) } \\
\hline Date & Diatoms & $\begin{array}{l}\text { Green } \\
\text { algae }\end{array}$ & $\begin{array}{l}\text { Cyano } \\
\text { bacteria }\end{array}$ & $\begin{array}{l}\text { Micro- } \\
\text { cystis }\end{array}$ & Flab & Bosmina & Cyclopoids & Asplanchna & Daphnids & Chydorids & $\begin{array}{l}\mathrm{CO} 2 \\
(\mathrm{aq})\end{array}$ & DIC \\
\hline 12-Feb & -35.1 & -42.3 & & & & -42.2 & -46.9 & -43.6 & & & -10.1 & -1.5 \\
\hline 3-March & -47.7 & -42.6 & & & & -39.5 & -40.4 & -35.8 & & & -6.0 & 2.8 \\
\hline 24-March & -39.5 & -36.0 & & & & -33.1 & & -48.9 & -38.5 & & -5.3 & 3.4 \\
\hline 22-April & -44.1 & -40.4 & & & & -34.2 & & -35.0 & & -35.6 & -7.6 & 1.1 \\
\hline 7-May & -40.7 & -34.9 & & -35.4 & & & & & & & -8.8 & -0.7 \\
\hline 19-May & & & -35.8 & & & & -38.2 & -36.8 & & & -11.3 & -2.5 \\
\hline 2-June & & & & & -21.5 & -36.3 & -36.1 & & -35.3 & -36.7 & -12.1 & -3.4 \\
\hline 25-June & -37.8 & -40.5 & -33.0 & -34.2 & & & & -40.9 & -39.2 & & -12.1 & -4.1 \\
\hline 8-July & -40.2 & -39.3 & -37.1 & -35.3 & -22.5 & & -39.3 & -37.2 & & -37.9 & -5.7 & 2.7 \\
\hline 5-Aug & & -36.9 & -33.7 & -33.5 & -24.0 & & -40.9 & -44.2 & & -39.6 & -6.7 & 0.3 \\
\hline $1-\mathrm{Sep}$ & -42.6 & -40.7 & -35.9 & -37.4 & & & -39.4 & & -40.8 & -39.8 & -11.0 & -3.1 \\
\hline 29-Sep & & -38.6 & -32.9 & -38.3 & & & -42.5 & & & & -10.4 & -2.7 \\
\hline $25-\mathrm{Nov}$ & -46.5 & -46.4 & -43.4 & & & -43.6 & -39.3 & -47.8 & & -41.8 & -11.7 & -3.6 \\
\hline Mean & -41.6 & -39.9 & -36.0 & -35.7 & -22.7 & -38.1 & -40.3 & -41.1 & -38.5 & -38.6 & -9.1 & -0.9 \\
\hline SE & 1.4 & 1.0 & 1.4 & 0.8 & 0.7 & 1.8 & 1.0 & 1.8 & 1.1 & 0.9 & 0.7 & 0.7 \\
\hline \multicolumn{13}{|l|}{ (c) } \\
\hline Date & Diatoms & $\begin{array}{l}\text { Green } \\
\text { algae }\end{array}$ & $\begin{array}{l}\text { Cyano } \\
\text { bacteria }\end{array}$ & $\begin{array}{l}\text { Micro- } \\
\text { cystis }\end{array}$ & Flab & Bosmina & Cyclopoids & Asplanchna & Daphnids & Chydorids & $\begin{array}{l}\mathrm{CO} 2 \\
\text { (aq) }\end{array}$ & DIC \\
\hline $\begin{array}{l}\text { 12-Feb } \\
\text { 3-March }\end{array}$ & -50.1 & -49.0 & & & & -46.4 & & & & & -7.1 & 1.5 \\
\hline 24-March & -46.7 & -42.1 & -44.3 & & & -39.7 & -36.6 & -42.3 & & & -8.8 & -0.1 \\
\hline 22-April & -38.7 & -36.7 & & & & -35.2 & -34.4 & -32.2 & -31.1 & -33.2 & -8.7 & 0.1 \\
\hline 7-May & -56.4 & -48.5 & -38.6 & & & & -43.5 & -47.9 & -40.9 & -43.7 & -11.4 & -3.1 \\
\hline 19-May & & & & -33.5 & & -38.6 & -36.9 & & -36.5 & -32.0 & -13.2 & -4.5 \\
\hline 2-June & -34.0 & -36.0 & -34.5 & & & & & -40.6 & & -36.5 & -12.6 & -4.1 \\
\hline 25-June & -33.3 & -38.4 & -42.5 & -36.4 & & -39.5 & -32.6 & -38.1 & & -36.2 & -8.5 & -0.1 \\
\hline 8-July & -32.0 & -31.5 & -35.8 & -33.5 & & & -31.1 & & & -34.6 & -8.1 & 0.7 \\
\hline 5-Aug & & -32.9 & -38.7 & -31.6 & & & & & & -36.5 & -9.6 & -0.8 \\
\hline $1-\mathrm{Sep}$ & & -34.2 & -39.0 & -32.9 & & -38.0 & -37.1 & -36.7 & & -38.0 & -9.0 & -0.4 \\
\hline 29-Sep & -37.6 & -35.5 & -41.0 & -32.8 & & -40.5 & -39.1 & -41.8 & & -40.3 & -8.0 & 0.4 \\
\hline $25-\mathrm{Nov}$ & -46.7 & -42.1 & -44.3 & & & -39.7 & -36.6 & -42.3 & & & -8.8 & -0.1 \\
\hline Mean & -41.1 & -38.5 & -39.3 & -33.4 & & -39.7 & -36.4 & -39.9 & -36.2 & -36.8 & -9.5 & -0.9 \\
\hline SE & 3.1 & 1.9 & 1.1 & 0.7 & & 1.3 & 1.4 & 1.9 & 2.8 & 1.2 & 0.6 & 0.6 \\
\hline
\end{tabular}


Acknowledgements. We thank G. ter Heerdt of the Municipal Waterworks of Amsterdam for providing additional data and inviting us to participate in the experimental setup. A. Bak, G. Bonhoff, V. Correa de la Torre are thanked for sampling and H. Hoogveld and K. Siewertsen for providing flow cytometer and zooplankton data. This publication is a contribution to OBN Restoration and Management of Dutch Peat lakes, financed by the Ministry of Agriculture, Nature and Fisheries in the Netherlands; a collaboration between the Universities of Nijmegen and Utrecht and the Centre for Limnology of the Netherlands Institute of Ecology. This is publication 3764 of the Netherlands Institute of Ecology (NIOO-KNAW).

Edited by: T. J. Battin

\section{References}

Bade, D. L., Carpenter, S. R., Cole, J. J., Hanson, P. C., and Hesslein, R. H.: Controls of $\delta^{13}$ C-DIC in lakes: Geochemistry, Lake metabolism and Morphometry, Limnol. Oceanogr., 49, 1160-1172, 2004.

Bade, D. L. and Cole, J. J.: Impact of chemically enhanced diffusion on dissolved inorganic carbon stable isotopes in a fertilized lake, J. Geophys. Res.-Oceans, 111, art. no. C01014, doi:10.1029/2004JC002684, 2006.

Baird, M. E., Emsley, S. M., and McGlade, J. M.: Using a phytoplankton growth model to predict the fractionation of stable carbon isotopes, J. Plankton Res., 23, 841-848, 2001.

Blokker, P., Pel, R., Akoto, L., Brinkman, U. A., and Vreuls, J. J.: At-line gas chromatographic-mass spectrometric analysis of FA profiles of green micro-algae using a direct thermal desorption interface, J. Chromatogr., 959, 191-201, 2002.

Boschker, H. T. S. and Middelburg, J. J.: Stable isotopes and biomarkers in microbial ecology, FEMS Microbiol. Ecol., 40, 85-95, 2002.

Boschker, H. T. S., Kromkamp, J. C., and Middelburg, J. J.: Biomarker and carbon isotopic constraints on bacterial and algal community structure and functioning in a turbid, tidal estuary, Limnol. Oceanogr., 50, 70-80, 2005.

Carpenter, S. R., Cole, J. J., Hodgson, J. R., Kitchell, J. F., Pace, M. L., Bade, D., Cottingham, K. L., Houser, J. N., and Schindler, D. E.: Trophic cascades, nutrients, and lake productivity: wholelake experiments, Ecol. Monogr., 71, 163-186, 2001.

Cassar, N., Laws, E. A., Bidigare, R. R., and Popp, B. N.: Bicarbonate uptake by Southern Ocean phytoplankton, Global Biogeochem. Cycles, 18, art. no. GB2003, 2004.

Chorus, I. and Bartram, J.: Cyanobacteria in the environment; organization, function and behaviour In Toxic cyanobacteria in water, WHO, England, 1999.

Cole, J. J., Pace, M. L., Carpenter, S. R., and Kitchell, J. F.: Persistence of net heterotrophy in lakes during nutrient addition and food web manipulations, Limnol. Oceanogr., 45, 1718-1730, 2000.

Craig, H.: The geochemistry of the stable carbon isotopes, Geochim. Cosmochim. Acta, 3, 53-92, 1953.

Finlay, J. C.: Patterns and controls of lotic algal stable carbon isotope ratios. Limnol. Oceanogr., 49, 850-861, 2004.

France, R. and Cattaneo, A.: $\delta^{13} \mathrm{C}$ variability of benthic algae: effects of water colour via modulation by stream current. Freshwa- ter Biol., 39, 617-622, 1998.

Freeman, K. H. and Hayes, J. M.: Fractionation of carbon isotopes by phytoplankton and estimates of ancient $\mathrm{CO}_{2}$ levels, Global Biogeochem. Cycles, 6, 185-198, 1992.

Goericke, R., Montoya, J. P., and Fry, B.: Physiology of isotopic fractionation in algae and cyanobacteria, pp. 187-221, in: Stable isotopes in ecology, edited by: Lajitha, K. and Michener, B., Blackwell Sci. Publ. Inc., Cambridge, 1994.

Gons, H. J., Burger-Wiersma, T., Otten, J. H., and Rijkeboer, M.: Coupling of phytoplankton and detritus in a shallow, eutrophic lake (Lake Loosdrecht, The Netherlands), Hydrobiologia, 233, 51-59, 1992b.

Gulati, R. D. and DeMott, W. R.: The role of food quality for zooplankton: remarks on the state-of-the-art, perspectives and priorities, Freshwater Biol., 38, 753-768, 1997.

Gulati, R. D. and van Donk, E.: Lakes in the Netherlands, their origin, eutrophication and restoration: state-of-the-art review, Hydrobiologia, 478, 73-106, 2002.

Herczeg, A. L. and Fairbanks, R. G.: Anomalous carbon isotope fractionation between atmospheric $\mathrm{CO}_{2}$ and dissolved inorganic carbon induced by intense photosynthesis, Geochim. Cosmochim. Acta, 51, 895-899, 1987.

Hosper, H. and Meijer, M.: Biomanipulation, will it work for your lake? A simple test for the assessment of chances for clear water, following drastic fish-stock reduction in shallow, eutrophic lakes, Ecol. Eng., 2, 63-72, 1993.

Jeppesen, E., Jensen, J. P., Søndergaard, M., Lauridsen, T., Pedersen, L. J., and Jensen, L.: Top-down control in freshwater lakes, the role of nutrient state, submerged macrophytes and water depth, Hydrobiologia, 342/343, 151-164, 1997.

Keller, K. and Morel, F. M. M.: A model of carbon isotopic fractionation and active carbon uptake in phytoplankton, Mar. Ecol. Prog. Ser., 182, 295-298, 1999.

Keough, J. E., Sierzen, M., and Hagley, C.: Analysis of a Lake Superior coastal food web with stable isotopes, Limnol. Oceanogr., 41, 136-146, 1996.

Kerner, M., Ertl, S., and Spitzy, A.: Trophic diversity within the planktonic food web of the Elbe Estuary determined on isolated individual species by ${ }^{13} \mathrm{C}$ analysis, J. Plankton Res., 26, 10391048, 2004.

Kling, G. W., Fry, B., and O'Brien, W. J.: Stable isotopes and planktonic trophic structure in arctic lakes, Ecology, 73, 561566, 1992.

Kott, P.: Modified whirling apparatus for sub sampling of plankton, Aust. J. Mar. Freshwater Res., 4, 387-393, 1953.

Laws, E. A., Popp, B. N., Bidigare, R. R., Kennicutt, M. C., and Macko, S. A.: Dependence of phytoplankton carbon isotopic composition on growth rate and $\left.\left[\mathrm{CO}_{2}\right) \mathrm{aq}\right]$ : Theoretical considerations and experimental results, Geochim. Cosmochim. Acta, 59, 1131-1138, 1995.

Laws, E. A., Bidigare, R. R., and Popp, B. N.: Effect of growth rate and $\mathrm{CO}_{2}$ concentration on carbon isotopic fractionation by the marine diatom Phaeodactylum tricornutu, Limnol. Oceanogr., 42, 1552-1560, 1997.

LaZerte, B. D. and Szalados, J. E.: Stable carbon isotope of submerged freshwater macrophytes, Limnol. Oceanogr., 27, 413418, 1982.

Leggett, M. F., Servos, M. R., Hesslein, R., Johannsson, O., Miljard, E. S., and Dixon, D. G.: Biogeochemical influences on the car- 
bon isotope signatures of Lake Ontario biota, Can. J. Fish Aquat. Sci., 56, 2211-2218, 1999.

Meijer, M., de Boois, I., Scheffer, M., Portielje, R., and Hosper, H.: Biomanipulation in shallow lakes in the Netherlands: an evaluation of 18 case studies, Hydrobiologia, 408/409, 13-30, 1999.

Middelburg, J. J., Barranguet, C., Boschker, H. T. S., Herman, P. M. J., Moers, T., and Heip, C. H. R.: The fate of intertidal microphytobenthos carbon: An in situ ${ }^{13} \mathrm{C}$-labeling study, Limnol. Oceanogr., 45, 1224-1234, 2000.

Miyajima, T., Yamada, Y., and Hanba, Y. T.: Determining the stable isotope ratio of total dissolved inorganic carbon in lake water by GC/C/IRMS, Limnol. Oceanogr., 40, 994-1000, 1995.

Mook, W. G., Bommerson, J. C., and Staverman, W. H.: Carbon isotope fractionation between dissolved bicarbonate and gaseous carbon dioxide, Earth Planet. Sci. Lett., 22, 169-176, 1974.

Pace, M. L., Cole, J. J., Carpenter, S. R., Kitchell, J. F., Hodgson, J. R., Van de Bogert, M. C., Bade, D. L., Kritzberg, E. S., and Bastviken, D.: Whole-lake carbon-13 additions reveal terrestrial support of aquatic food webs, Nature, 427, 240-243, 2004.

Pel, R., Hoogveld, H., and Floris, V.: Using the hidden isotopic heterogeneity in phyto- and zooplankton to unmask disparity in trophic carbon transfer, Limnol. Oceanogr., 48, 2200-2207, 2003.

Pel, R., Floris, V., and Hoogveld, H.: Analysis of planktonic community structure and trophic interactions using refined isotopic signatures determined by combining fluorescence-activated cell sorting and isotope-ratio mass spectrometry, Freshwater Biol., 49, 546-562, 2004a.

Pel, R., Floris, V., Gons, H. J., and Hoogveld, H. L.: Linking flow cytometric cell sorting and compound-specific ${ }^{13} \mathrm{C}$-analysis to determine population-specific isotopic signatures and growth rates in cyanobacteria-dominated lake plankton, J. Phycol., 40, 857-866, 2004b.

Petersen, C. G. J.: The yearly immigration of young plaice into the Limfjord from the German Sea, Rep. Dan. Biol. Stn., 6, 1-48, 1896.

Peterson, B. J. and Fry, B.: Stable isotopes in ecosystem studies, Annu. Rev. Ecol. Syst., 18, 293-320, 1987.

Prieto, F. J. and Millero, F. J.: The values of $\mathrm{pK}_{1}+\mathrm{pK}_{2}$ for the dissociation of carbonic acid in seawater, Geochim. Cosmochim. Acta, 66, 2529-2540, 2002.
Rau, G. H.: Carbon-13 depletion in a subalpine lake: carbon flow implications, Science, 201, 901-902, 1978.

Rounick, J. S. and Winterbourn, M. J.: Stable carbon isotopes and carbon flow in ecosystems, Bioscience, 36, 171-177, 1986.

Scheffer, M.: Ecology of Shallow Lakes, Chapman \& Hall, London, 1998.

Schindler, D. E., Carpenter, S. R., Cole, J. J., Kitchell, F., and Pace, M. L.: Influence of food web structure on carbon exchange between lakes and the atmosphere, Science, 277, 248-251, 1997.

Sierszen, M. E., Morrice, J. A., Moffett, M. F., and West, C. W.: Benthic versus planktonic foundations of three Lake Superior coastal wetland food webs, J. Great Lakes Res., 30, 31-43, 2004.

Søndergaard, M., Jensen, J. P., and Jeppesen, E.: Role of sediment and internal loading of phosphorus in shallow lakes, Hydrobiologia, 506-509, 135-145, 2003.

Steiner, C. F.: Daphnia dominance and zooplankton community structure in fishless lakes, J. Plankton Res., 26, 799-810, 2004.

Van den Meersche, K., Middelburg, J. J., Soetaert, K., van Rijswijk, P., Boschker, H. T. S., and Heip, C. H. R.: Carbon-nitrogen coupling and algal-bacterial interactions during an experimental bloom: Modeling a ${ }^{13} \mathrm{C}$-tracer experiment, Limnol. Oceanogr., 49, 862-878, 2004.

Van Donk, E., Grimm, M. P., Heuts, P. G. M., Blom, G., Everards, K., and Van Tongeren, O. F. R.: Use of mesocosms in a shallow eutrophic lake to study the effects of different restoration measures, Arch. Hydrobiol., 40, 283-294, 1994.

Veuger, B., Middelburg, J. J., Boschker, H. T. S., and Houtekamer, M.: Analysis of ${ }^{15} \mathrm{~N}$ incorporation into D-alanine: A new method for tracing nitrogen uptake by bacteria, Limnol. Oceanogr. Methods, 3, 240-250, 2005.

Wanninkhof, R. and Knox, M.: Chemical enhancement of $\mathrm{CO}_{2}$ exchange in natural waters, Limnol. Oceanogr., 41, 689-697, 1996.

Welschmeyer, N. A. and Lorenzen, C. J.: Carbon-14 labeling of phytoplankton carbon and chlorophyll a carbon: Determination of specific growth rates, Limnol. Oceanogr., 29, 135-145, 1984.

Zöllner, E., Santer, B., Boersma, M., Hoppe, H. G., and Jürgens, K.: Cascading predation effects of Daphnia and copepods on microbial food webs components, Freshwater Biol., 48, 2174 2193, 2003. 